\title{
The Polymodal Ion Channel Transient Receptor Potential Vanilloid 4 Modulates Calcium Flux, Spiking Rate, and Apoptosis of Mouse Retinal Ganglion Cells
}

\author{
Daniel A. Ryskamp, ${ }^{1,2 \star}$ Paul Witkovsky, ${ }^{4 \star}$ Peter Barabas, ${ }^{1 \star}$ Wei Huang, ${ }^{1}$ Christopher Koehler, ${ }^{5}$ Nikolay P. Akimov, ${ }^{5}$ \\ Suk Hee Lee, ${ }^{6}$ Shiwani Chauhan, ${ }^{1}$ Wei Xing, ${ }^{1}$ René C. Rentería, ${ }^{5}$ Wolfgang Liedtke, ${ }^{6}$ and David Križaj ${ }^{1,2,3}$ \\ ${ }^{1}$ Department of Ophthalmology \& Visual Sciences, John A. Moran Eye Center, ${ }^{2}$ Interdepartmental Program in Neuroscience, and ${ }^{3}$ Department of \\ Physiology, University of Utah School of Medicine, Salt Lake City, Utah 84132, ${ }^{4}$ Department of Ophthalmology, New York University School of Medicine, \\ New York, New York 10016, ${ }^{5}$ Department of Physiology and Center for Biomedical Neuroscience, University of Texas Health Science Center at San Antonio, \\ San Antonio, Texas, and ' ${ }^{2}$ epartment of Medicine and Neurobiology, and Center for Translational Neuroscience, Duke University Medical Center, Durham, \\ North Carolina 27710
}

Sustained increase in intraocular pressure represents a major risk factor for eye disease, yet the cellular mechanisms of pressure transduction in the posterior eye are essentially unknown. Here we show that the mouse retina expresses mRNA and protein for the polymodal transient receptor potential vanilloid 4 (TRPV4) cation channel known to mediate osmotransduction and mechanotransduction. TRPV4 antibodies labeled perikarya, axons, and dendrites of retinal ganglion cells (RGCs) and intensely immunostained the optic nerve head. Müller glial cells, but not retinal astrocytes or microglia, also expressed TRPV4 immunoreactivity. The selective TRPV4 agonists $4 \alpha$-PDD and GSK1016790A elevated $\left[\mathrm{Ca}^{2+}\right]_{\mathrm{i}}$ in dissociated RGCs in a dose-dependent manner, whereas the TRPV1 agonist capsaicin had no effect on $\left[\mathrm{Ca}^{2+}\right]_{\mathrm{RGC}}$. Exposure to hypotonic stimulation evoked robust increases in $\left[\mathrm{Ca}^{2+}\right]_{\mathrm{RGC}}$. RGC responses to TRPV4-selective agonists and hypotonic stimulation were absent in $\mathrm{Ca}^{2+}$-free saline and were antagonized by the nonselective TRP channel antagonists Ruthenium Red and gadolinium, but were unaffected by the TRPV1 antagonist capsazepine. TRPV4-selective agonists increased the spiking frequency recorded from intact retinas recorded with multielectrode arrays. Sustained exposure to TRPV4 agonists evoked dose-dependent apoptosis of RGCs. Our results demonstrate functional TRPV4 expression in RGCs and suggest that its activation mediates response to membrane stretch leading to elevated $\left[\mathrm{Ca}^{2+}\right]_{\mathrm{i}}$ and augmented excitability. Excessive $\mathrm{Ca}{ }^{2+}$ influx through TRPV4 predisposes RGCs to activation of $\mathrm{Ca}^{2+}$-dependent proapoptotic signaling pathways, indicating that TRPV4 is a component of the response mechanism to pathological elevations of intraocular pressure.

\section{Introduction}

Cells of multicellular organisms experience mechanical stimuli that range from the direct mechanical impact of pulling and stretching to changes in osmotic and hydrostatic pressure (Wang and Thampatty, 2006; Bourque, 2008). Mechanical stretch or pressure activates ion channels in the plasma membrane (Loukin et al., 2010a,b), resulting in depolarization, increased intracellu-

\footnotetext{
Received Jan. 20, 2011; revised March 10, 2011; accepted March 26, 2011.

Author contributions: D.A.R. and D.K. designed research; D.A.R., P.W., P.B., W.H., C.K., N.P.A., S.H.L., S.C., W.X., R.C.R., and D.K. performed research; W.L. contributed unpublished reagents/analytic tools; D.A.R., P.W.,P.B., R.C.R., W.L., and D.K. analyzed data; D.K. wrote the paper.

The work was supported by the National Institutes of Health (Grants T32DC008553, R01EY13870, and P30EY014800), the International Retina Research Foundation, the Richard H. Chartrand Foundation, The Foundation Fighting Blindness, the Neuroscience Program at the University of Utah, and the Moran TIGER award. The research was also supported by unrestricted grants from Research to Prevent Blindness to the Moran Eye Institute at the University of Utah. We thank Dr. Ning Tian (University of Utah) for the gift of Thy1:CFP mice and Thy1:GFP sections; and Dr. Tünde Molnar and Ms. Carolyn Groves for help with data analysis.

*D.A.R., P.W., and P.B. contributed equally to this work.

Correspondence should be addressed to David Križaj, Department of Ophthalmology \& Visual Sciences, John A. Moran Eye Center, University of Utah School of Medicine, Salt Lake City, UT 84132. E-mail: david.krizaj@ hsc.utah.edu.

DOI:10.1523/JNEUROSCI.0359-11.2011

Copyright $\odot 2011$ the authors $\quad 0270-6474 / 11 / 317089-13 \$ 15.00 / 0$
}

lar $\mathrm{Ca}^{2+}$ concentration $\left(\left[\mathrm{Ca}^{2+}\right]_{\mathrm{i}}\right)$ (Zabel et al., 1996; Wu and Davis, 2001), and changes in gene expression, cell shape, and cytoskeletal organization (Naruse et al., 1998; Thodeti et al., 2009).

Recent studies have established that members of the transient receptor potential (TRP) superfamily transduce visual, chemical, thermal, mechanical, painful, and osmotic stimuli into $\mathrm{Ca}^{2+}$ fluxes (for review, see Liedtke and Kim, 2005; Kung, 2005; Christensen and Corey, 2007; Sharif-Naeini et al., 2008). We are particularly interested in the possibility that the vertebrate retina, which is exposed to systemic blood pressure, hydrostatic pressure from the CSF, and intrinsic intraocular pressure (IOP), contains one or more pressure-sensitive TRP channels. Pathological elevations in IOP or systemic pressure represent primary risk factors for glaucoma, a group of inherited optic neuropathies characterized by apoptotic loss of retinal ganglion cells (RGCs), degeneration of the optic nerve, and progressive loss of visual fields (Quigley, 2005; Whitmore et al., 2005). The cellular pathophysiology of glaucoma is not well understood, in part because the mechanisms that couple the mechanical stimulus $(\Delta \mathrm{IOP})$ to cellular signal transduction remain to be characterized. 
In eukaryotic cells, the TRP vanilloid 4 (TRPV4) channel (GenBank accession number NM_022017) represents a polymodal mechanism that transduces osmotic pressure, shear force stimuli, mechanical stretch, and moderate warmth $\left(\sim 27-37^{\circ} \mathrm{C}\right)$ into cation influx with a preference for $\mathrm{Ca}^{2+}\left(\mathrm{P}_{\mathrm{Ca}} / \mathrm{P}_{\mathrm{Na}} \sim 6\right)$ (Liedtke et al., 2000; Güler et al., 2002; O'Neil and Heller, 2005). The channel may be activated by intracellular mediators such as arachidonic acid and cytochrome P450-dependent formation of 5,6-epoxyeicosatrienoic acid (Vriens et al., 2004, but see Loukin et al., 2009). In neural tissues, TRPV4 expression has been localized to sensory neurons in dorsal root and trigeminal ganglia, inner ear hair cells, Merkel cells, hippocampal and hypothalamic neurons, and astrocytes (Liedtke et al., 2000; Reiter et al., 2006; Benfenati et al., 2007; Shibasaki et al., 2007; Alessandri-Haber et al., 2009). Mice lacking TRPV4 have defects in noxious mechanosensation and pressure sensation (Liedtke and Friedman, 2003; Suzuki et al., 2003), whereas the functional ortholog of TRPV4 in the worm Caenorhabditis elegans, OSM-9, mediates osmotic, mechanical, and chemical avoidance (Liedtke et al., 2003). Together, these findings suggest that TRPV4 represents an evolutionarily conserved element of the neural response to mechanical stimulation.

We report here that TRPV4 is expressed in RGC somata and optic axon fibers. Transient activation of TRPV4 induced $\mathrm{Ca}^{2+}$ influx and increased the excitability of ganglion cells, whereas sustained activation resulted in RGC apoptosis. The prominent expression of TRPV4-immunoreactivity (IR) at the optic nerve head $(\mathrm{ONH})$, and the role of TRPV4 in gating $\mathrm{Ca}^{2+}$ entry and RGC firing, implicate this channel in the retinal remodeling that occurs during chronic increases in IOP.

\section{Materials and Methods}

\section{Animals}

C57BL/6J mice of either sex were obtained from commercial suppliers, whereas B6.Cg- $\operatorname{Tg}$ (Thy1-CFP)23Jrs/J (hereafter, Thy1:CFP) animals or retinal sections were a kind gift from Dr. Ning Tian (University of Utah, Salt Lake City, UT). The animals were maintained in the University animal quarters on a $12 \mathrm{~h}$ light/dark cycle. Mice were fed lab chow and water ad libitum. Mice were killed before isolation and dissociation of retinas (Duncan et al., 2006). Animal handling and anesthetic procedures were approved by University Institutional Animal Care committees and conform to National Institutes of Health guidelines.

\section{Histology}

Eyes were enucleated, and their corneas and lenses dissected away. The remaining posterior pole of the eye was fixed by immersion for $1 \mathrm{~h}$ at room temperature in freshly prepared $4 \%$ paraformaldehyde in $0.1 \mathrm{M}$ phosphate buffer, $\mathrm{pH} 7.2$, then washed $3 \times 10 \mathrm{~min}$ in $\mathrm{pH} 7.2 \mathrm{PBS}$. Fixed eye tissue was then immersed for $12-16 \mathrm{~h}$ in $30 \%$ sucrose at $4^{\circ} \mathrm{C}$, embedded in OCT (Ted Pella), cryostat sectioned at $16 \mu \mathrm{m}$, and mounted on Superfrost slides (Fisher Scientific). After drying for $1 \mathrm{~h}$ at $37^{\circ} \mathrm{C}$, slides were stored frozen $\left(-80^{\circ} \mathrm{C}\right)$ until used. Dissociated cells were isolated with papain (7 U/ml; Worthington), plated on concanavalin A-coated coverslips, fixed in $4 \%$ paraformaldehyde in $0.1 \mathrm{~m}$ phosphate buffer, $\mathrm{pH}$ 7.2 , for $30 \mathrm{~min}$, washed $3 \times 10 \mathrm{~min}$ in $\mathrm{pH} 7.2 \mathrm{PBS}$, and stored at $4^{\circ} \mathrm{C}$.

Immunohistochemistry. For fluorescence immunocytochemistry, cryostat sections were thawed and washed in PBS, then placed for $30 \mathrm{~min}$ to $1 \mathrm{~h}$ in blocking solution (10 ml of PBS, $30 \mu \mathrm{l}$ of Triton X-100, $100 \mathrm{mg}$ of bovine serum albumin, $100 \mu \mathrm{l}$ of $10 \% \mathrm{w} / \mathrm{v} \mathrm{Na}$ azide solution). Primary and secondary antibodies were diluted in blocking solution and applied for 2 and $1 \mathrm{~h}$, respectively, at room temperature, with three intervening washes in PBS. After a final set of washes in PBS, the sections were covered in VectaShield (Vector Laboratories).

Terminal deoxynucleotidyl transferase-mediated dUTP-biotin nick end labeling assay. Retinas were embedded, cryosectioned, and processed for terminal deoxynucleotidyl transferase-mediated biotinylated UTP nick

\section{Table 1. Primary antibodies and their sources and dilutions}

\begin{tabular}{lll}
\hline Target & Company & Catalog number \\
\hline TRPV4 & Alomone Labs & ACC-034 rabbit 1:500 -1:1000 \\
TRPV4 & MBL International Corporation & LS-A8583 rabbit 1:200-1:1000 \\
TRPV4 & Affinity Bioreagents/Thermo Scientific & OSR00136W rabbit 1:200-1:1000 \\
& $\quad$ Pierce/OSenses & \\
TRPV4 & Abcam & Ab63003 rabbit 1:200-1:1000 \\
TRPV4 & Lifespan Biosciences & LS-C94498 rabbit 1:200-1:1000 \\
Brn3a & Santa Cruz Biotechnology & Sc-8429 mouse 1:100 \\
Cone arrestin & Gift from Dr. Wolfgang Baehr (University & Mouse 1:100 -1:500 \\
& of Utah) & \\
Rhodopsin & Santa Cruz Biotechnology & Sc-57433 mouse 1:100 \\
ChAT & Chemicon & AB144-P goat 1:200 \\
GAD-65 & Developmental Studies Hybridoma & GAD-6 mouse 1:1000 \\
& Bank & \\
GFAP & Sigma & G3893 mouse 1:500 \\
GFP & Santa Cruz Biotechnology & Sc-9996 mouse 1:100 -1:500 \\
\hline
\end{tabular}

end labeling (TUNEL) following the protocol by Gavrieli et al. (1992). After 30 min rehydration in $70 \%$ ethanol, $2 \times 5$ min rinses in PBS and $1 \%$ Triton-X in $1 \%$ citrate buffer, $\mathrm{pH} 7.3$, the slides were subjected to a final rinse in PBS. Slides were then incubated for $30 \mathrm{~min}$ in the reaction buffer (30 mm Trizma-HCl, $140 \mathrm{~mm} \mathrm{Na}^{+}$cacodylate, $1.0 \mathrm{~mm} \mathrm{CaCl}_{2}, 0.2 \%$ Triton X-100, pH 7.2). Positive controls were treated with DNase I (Roche Diagnostics) $(10 \mathrm{U} / \mathrm{ml})$ in the reaction buffer. Next, slides were treated for $1 \mathrm{~h}$ with $0.03 \mathrm{U} / \mu \mathrm{l}$ terminal transferase and $4 \mu \mathrm{M}$ biotin-16-dUTP (Roche Diagnostics). The reaction was terminated in $30 \mathrm{~mm} \mathrm{Na}^{+}$citrate, $300 \mathrm{~mm} \mathrm{NaCl}$, and $0.2 \%$ Triton X-100 in PBS (5 min), and rinsed in PBS $(2 \times 5 \mathrm{~min})$, exposed to $1 \%$ bovine serum albumin in PBS for $20 \mathrm{~min}$, and rinsed. As a negative control, the retinal sections were processed omitting the incubation step with terminal deoxynucleotidyl transferase during DNA labeling. Apoptotic cells were visualized with a confocal microscope (LSM510; Zeiss) and categorized by size. We found that our fixation protocol resulted in $\sim 1 \mu \mathrm{m}$ shrinkage in the diameter of dissociated Brn3a-IR cells in retinal sections. Therefore, the TUNEL analysis compared cells with a diameter of $>6 \mu \mathrm{m}$ (presumed RGCs) to photoreceptor cells with diameters of $3-5 \mu \mathrm{m}$ (the identity of photoreceptors was confirmed by immunostaining for mouse cone arrestin (a gift from Dr. Wolfgang Baehr, University of Utah, Salt Lake City, UT) and rhodopsin (Santa Cruz Biotechnology). A cell was deemed to be TUNEL positive if the fluorescent signal completely filled the cell body.

\section{Image acquisition and processing}

Sections were examined by confocal microscopy (LSM 510, Zeiss; or PM 800, Nikon). Digital images were acquired separately from each laser channel, then recombined. Files were further processed with deconvolution software (AutoQuant Imaging). Adjustments of contrast and intensity were made in Photoshop (Adobe); any such adjustments were made uniformly to the entire image.

\section{Western blot}

We essentially followed the procedure outlined in previous publications (Liedtke and Friedman, 2003; Phan et al., 2009). In brief, homogenized retinal tissue was subjected to protein preparation and denaturation, and proteins (10 $\mu \mathrm{g}$ per lane) were separated on an SDS gel, then immunoblotted to polyvinylidene difluoride membranes. After blocking with milk powder, TRPV4 was immunodetected using the above antibody (Phan et al., 2009) and peroxidase-based chemoluminescence.

\section{Primary and secondary antibodies}

Table 1 shows the primary and secondary antibodies used in this study. Multiple commercially available anti-TRPV4 antibodies (ACC-034, Alomone Labs; LS-A8583, MBL International Corporation; OSR00136W, Affinity Bioreagents; and ab63003, Abcam) were tested by immunostaining and Western blots in wild-type and TRPV4-null mice. However, the only antibody that proved completely satisfactory was LS-C94498 (Lifespan Biosciences), based on the following criteria: (1) The antibody stained Western blot bands of 85 and $106 \mathrm{kDa}$ from retinal tissue har- 
vested from wild-type mice but not from TRPV4-null mice (see Fig. 1); (2) it colocalized with green fluorescent protein (GFP) in RGCs from transgenic animals in which GFP was driven by the Trpv4 gene promoter (see Fig. 2C); and (3) it detected protein bands of appropriate molecular mass from HEK293 cells transfected with Trpv4 cDNA, whereas the bands were missing in immunoblots from nonexpressing cells (Fig. 1). All TRPV4-IR data reported in the present study were obtained with the anti-TRPV4 antibody LS-C94498. No immunostaining was observed when the primary antibody was omitted.

\section{Semiquantitative RT-PCR}

Total RNA from retina was extracted with Trizol, and total RNA ( $2 \mu \mathrm{g}$ of total RNA used for first-strand synthesis with oligo-dT and primers) was converted to cDNA using the SuperScript III First-Strand Synthesis kit from Invitrogen. PCR products were amplified in a thermocycler (Veriti, $\mathrm{ABI}$ ) with nucleic acid stain (SYBR Green, $\mathrm{ABI}$ ) reagents according to the manufacturer's instructions. Amplification of PCR products was measured by fluorescence associated with binding of double-stranded DNA to SYBR Green in the reaction mixture. After an initial denaturation step of $50^{\circ} \mathrm{C}$ for $2 \mathrm{~min}$ and $95^{\circ} \mathrm{C}$ for $10 \mathrm{~min}, \mathrm{PCR}$ was repeated for $40 \mathrm{cycles}$ at $95^{\circ} \mathrm{C}$ for $15 \mathrm{~s}, 58^{\circ} \mathrm{C}$ for $30 \mathrm{~s}$, and $72^{\circ} \mathrm{C}$ for $30 \mathrm{~s}$. After amplification, the ratio of gene-of-interest mRNA to a housekeeping gene, glyceraldehyde3-phosphate dehydrogenase (Gapdh), was calculated for each sample. Five to 10 independent biological replicates (retinas) were used at each age.

Generation of a bacterial artificial chromosome transgenic mouse line with a fluorescent reporter driven by the Trpv4 promoter A mouse bacterial artificial chromosome (BAC) harboring the Trpv4 gene was modeled by "recombineering" (Copeland et al., 2001), so that the copepod-GFP coding region was placed directly after the ATG start codon of mouse Trpv4. In addition, this BAC was engineered to not harbor exons $10-14$, so that a functional ion channel could not arise from the transgene. Engineered DNA served as a transgenesis template, which was constructed following standard procedures (Zhao et al., 2008). Of four resulting transgenic lines, the one used revealed robust fluorescence in trigeminal ganglion sensory neurons (not illustrated), both in acute sections and acute dissociations, colocalizing with TRPV4 immunolabeling. This line was outcrossed for five or more generations before analysis of retinas.

\section{Calcium imaging}

Calcium imaging was performed on acutely isolated retinal cells, as described previously (Szikra et al., 2009). In brief, dissociated retinal cells were plated on concanavalin A-coated $(0.2 \mathrm{mg} / \mathrm{ml}$; Sigma) coverslips, loaded with fura-2 AM (1-5 $\mu \mathrm{M}$; Invitrogen) for 15-30 min and washed for $10 \mathrm{~min}$ in dye-free L-15 medium. Cells were viewed with Nikon Ti inverted or $600 \mathrm{EF}$ upright microscopes using $20 \times 0.95$ numerical aperture (NA), $40 \times 0.85 \mathrm{NA}$, or $40 \times 1.25 \mathrm{NA}$ objective lenses. Excitation for 340 and $380 \mathrm{~nm}$ filters (Chroma and Semrock) was provided by a $150 \mathrm{~W}$ Xenon arc lamp (DG4, Sutter Instruments). Fluorescence emission was high-pass filtered at $510 \mathrm{~nm}$ and captured with cooled digital CCD cameras (HQ2, Photometrics). Data acquisition and $\mathrm{F}_{340} / \mathrm{F}_{380}$ ratio calculations were performed by NIS Elements software. Fluorescence imaging was performed on regions of interest (ROIs) encompassing the RGC perikaryon, typically at $3 \times 3$ binning. Background fluorescence was measured in similarly sized ROIs in neighboring areas devoid of cells. After sequential image acquisition $(0.167-0.5 \mathrm{~Hz})$ of cell fluorescence at $340 / 380 \mathrm{~nm}$, the background was subtracted. Calibration of free $\left[\mathrm{Ca}^{2+}\right]_{\mathbf{i}}$ was performed in vivo using $10 \mu \mathrm{M}$ ionomycin and $10 \mathrm{mM} \mathrm{Ca}^{2+}$ or 0 $\mathrm{Ca}^{2+} / 3$ mM EGTA. The apparent free $\left[\mathrm{Ca}^{2+}\right]_{\mathbf{i}}$ was determined from the equation $\left[\mathrm{Ca}^{2+}\right]_{\mathbf{i}}=\left(\left(R-R_{\min }\right) /\left(R_{\max }-R\right)\right) \times\left(\mathrm{F}_{\max }^{380} / \mathrm{F}^{380}{ }_{\min }\right) \times K_{\mathrm{d}}$, where $R$ is the ratio of emission intensity at $510 \mathrm{~nm}$ evoked by $340 \mathrm{~nm}$ excitation versus emission intensity at $510 \mathrm{~nm}$ evoked by $380 \mathrm{~nm}$ excitation, $R_{\min }$ is the ratio at zero free $\mathrm{Ca}^{2+}, R_{\max }$ is the ratio at saturating $\mathrm{Ca}^{2+}$, and the dissociation constant $K_{\mathrm{d}}$ for $\mathrm{Ca}^{2+}$-fura 2 at room temperature was taken to be $224 \mathrm{~nm}$ (Neher, 1995). Glutamate (100 $\mu \mathrm{M})$ was added at the beginning of each experiment to control for neuronal health, type, and responsiveness. DMSO, the solvent for the indicator dye, did not induce any responses in RGCs (data not shown). Previous studies using $\mathrm{Mn}^{2+}$ quenching showed that $95 \%$ of the fura-2 fluorescence emanates from the cytosol in the cells (Szikra et al., 2009). Experiments were conducted at room temperature, and encompassed stimulation with glutamate, TRPV4, and TRPV1 agonists and antagonists.

\section{Cell identification}

RGCs in short-term culture were identified initially by morphology and perikaryal size $(7-15 \mu \mathrm{m})$. In a subset of experiments, RGCs isolated from Thy1:CFP retinas were used and identified by intrinsic fluorescence (Raymond et al., 2009). Alternatively, test neurons isolated from wildtype retinas were confirmed as RGCs by immunocytochemistry. In each experiment, a $100 \mu \mathrm{M}$ glutamate stimulus was used to confirm that the visually identified putative RGCs expressed ionotropic glutamate receptors. Presumed RGCs responded to $30 \mathrm{~mm} \mathrm{KCl}$ with rapid highamplitude increases in $\left[\mathrm{Ca}^{2+}\right]_{\mathfrak{i}}$, indicating that the cells were healthy and maintained their excitability. In a subset of experiments, cells recorded during stimulation with hypotonic saline or TRPV4 agonists were fixed and immunostained with TRPV4 and Brn3a antibodies.

\section{Solutions and reagents}

The isotonic superfusing saline contained the following (in $\mathrm{mm}$ ): 133 $\mathrm{NaCl}, 2.5 \mathrm{KCl}, 2 \mathrm{CaCl}_{2}, 1.5 \mathrm{MgCl}_{2}, 1.25 \mathrm{NaH}_{2} \mathrm{PO}_{4}, 10$ HEPES hemisodium salt, 10 glucose, 1 pyruvic acid, 1 lactic acid, and 0.5 glutathione. In $\mathrm{Ca}^{2+}$-free solutions, no external $\mathrm{Ca}^{2+}$ was added, and the saline was supplemented with $1 \mathrm{~mm}$ EGTA. The osmolarity and $\mathrm{pH}$ of each external solution was measured before each experiment. $\mathrm{pH}$ was adjusted to 7.4 with $\mathrm{NaOH}$. Osmolarity was measured with a vapor-pressure osmometer (VAPRO); for control saline, osmolarity was $280 \mathrm{mOsm}$. For experiments involving hypotonic stimulation, the isotonic ringer contained $132 \mathrm{~mm}$ mannitol and the $\mathrm{NaCl}$ concentration was reduced to $57.5 \mathrm{~mm}$. Hypoosmotic solutions were prepared by reducing the final concentration of mannitol to $44.5 \mathrm{~mm}$ without changing the ionic composition. In a subset of experiments using hypotonic stimulation, cells were coloaded with fura-2 AM + calcein AM (1 $\mu \mathrm{M}$; Invitrogen). Calcein fluorescence was elicited using $490 \mathrm{~nm}$ excitation filters. Because calcein fluorescence is $\mathrm{Ca}^{2+}$ independent and volume dependent, it was used as a measure of changes in the cell volume.

Unless otherwise indicated, the salts and reagents were purchased from Sigma. Ruthenium Red and capsaicin were purchased from Ascent Scientific. Capsaicin and capsazepine were also purchased from Tocris. $4 \alpha$-PDD was obtained from LC Laboratories.

\section{Multielectrode array recordings and data analysis}

Multielectrode array (MEA) recordings were performed using multielectrode, extracellular recording chambers (MEA1060 system, MultiChannel Systems) consisting of an array of 60 planar electrodes, each $10 \mu \mathrm{m}$ in diameter, spaced $100 \mu \mathrm{m}$ apart for a total array size of $700 \mu \mathrm{m}^{2}$, as described previously (Rentería et al., 2006). Briefly, young adult C57BL6] mice were killed after $1 \mathrm{~h}$ of dark adaptation, and an eye was removed under dim red illumination. The retina was dissected and placed with the ganglion cell side against the recording electrodes using a piece of nitrocellulose paper as support. The retina was typically placed on the array within a millimeter of the optic nerve head, and a manipulator (Cell Micro Controls) was used to hold the tissue down with slight pressure. Retinas were perfused at room temperature for $30 \mathrm{~min}$ and at $30^{\circ} \mathrm{C}$ for another $30 \mathrm{~min}$ before recordings were started, the temperature was maintained at $30^{\circ} \mathrm{C}$ thereafter, and spontaneous spiking in the dark was recorded. The perfusion saline was either Ames' medium or Ringer's modified solution as follows (in mM): $124 \mathrm{NaCl}, 2.5 \mathrm{KCl}, 2 \mathrm{CaCl}_{2}, 2$ $\mathrm{MgCl}_{2}, 1.25 \mathrm{NaH}_{2} \mathrm{PO}_{4}, 26 \mathrm{NaHCO}_{3}$, and 22.2 glucose; the $\mathrm{pH}$ was maintained at $7.3-7.4$ by bubbling with $95 \% \mathrm{O}_{2} / 5 \% \mathrm{CO}_{2}$ mixed gas. Voltage signals sampled at $50 \mathrm{kHz}$ were bandpass filtered at $100 \mathrm{~Hz}$ to $3 \mathrm{kHz}$, and waveforms that crossed a negative voltage threshold (set at -5.5 SDs of the mean noise) were recorded to disk for off-line analysis. Under these conditions, nearly all recorded cells are likely to be RGCs (Rentería et al., 2006).

Spike trains for each RGC were determined by spike sorting based on clustering in principal component space using software (Offline Sorter, Plexon). Not every detected waveform was assigned to a unit; obvious automatic sorting errors were corrected for each cluster manually (Rentería et al., 
2006). Time stamps of the action potentials of each sorted unit were used to generate peristimulus time histograms ( $30 \mathrm{~s}$ bins). The average spike rates during the 3 min period before and after drug application were determined for every recorded cell and expressed as the percentage change in firing in the presence of drug. This normalization allowed for comparison of cells with varied initial spike rates. The very few cells that had zero rates before application and spiking during drug application were considered to have increased by $100 \%$.

\section{Statistical analysis}

Data are expressed as the mean \pm SEM, with the number of cells, slides, or animals indicated by $N$. Cell diameter data are expressed as the mean \pm SD. Statistical comparisons between two treatments in the same cell were determined using the $t$ test; unless indicated otherwise, comparisons between different groups were evaluated by the Mann-Whitney test or the Wilcoxon signed rank test. Data obtained in multielectrode array studies were analyzed with the Wilcoxon signed rank test. A value of $p<0.05$ was considered statistically significant.

\section{Results}

\section{TRPV4 mRNA and protein in the mouse retina}

RT-PCR was performed using total RNA extracted from adult (postnatal day 90) mouse retinas. Gel analysis revealed PCR products at the appropriate size of $174 \mathrm{bp}$. The same transcript was amplified in kidney tissue, known to express Trpv4 (Strotmann et al., 2000, Liedtke et al., 2000; Güler et al., 2002) (Fig. 1A).

We next compared TRPV4 protein expression in tissues derived from wild-type and TRPV4-null mice (see Materials and Methods). Consistent with RT-PCR, immunoblots from wildtype mouse retinas showed a primary band of $85 \mathrm{kDa}$ and a secondary band at $105 \mathrm{kDa}$, which probably correspond to unglycosylated and $N$-glycosylated forms of TRPV4, respectively, which is in keeping with previous reports (Fig. $1 B$ ) (Liedtke and Friedman, 2003; Benfenati et al., 2007; Hartmannsgruber et al., 2007). Both bands were absent in retinal tissue derived from TRPV4-null mice (Fig. 1B). The TRPV4 antibody was validated in Western blots from HEK293 cells transfected with Trpv4 cDNA (Fig. 1C) and in trigeminal ganglion tissue known to robustly express Trpv4 (Liedtke et al., 2000; Liedtke and Friedman, 2003). As an additional test of the TRPV4 antibody, we immunostained the kidney, choroid plexus, and nodose ganglion tissues in which TRPV4 is expressed (Liedtke et al., 2000; Strotmann et al., 2000; Brierley et al., 2008). The patterns of TRPV4 expression in these tissues were identical to those identified in previous reports (data not shown). For example, the somata of neurons within the nodose ganglion (Fig. $1 \mathrm{Di}$ ) were strongly TRPV4 immunoreactive, whereas the nodose tissue from a TRPV4-null mouse was unlabeled by the TRPV4 antibody (Fig. 1 Dii).

\section{TRPV4 immunoreactivity in the mouse retina}

$T R P V 4-I R$ in retinal ganglion cells

In wild-type mouse retinas, TRPV4-IR was punctate and distributed throughout the inner retina (Fig. $2 A$ ). A dense array of TRPV4-IR puncta was seen within cell bodies located in the ganglion cell layer ( $\mathrm{gcl})$. TRPV4-IR was distributed at a lower density throughout the inner plexiform layer (ipl), but only very sparse TRPV4-IR was located within the inner nuclear layer (inl). This immunostaining pattern was absent in retinas of TRPV4-null mice (Fig. $2 B$ ). The apparent immunostaining of the outer plexiform layer (opl) is nonspecific since it was identical in wild-type and TRPV4-null retinas (Fig. 2A,B). Within the outer nuclear layer (onl) consisting primarily of photoreceptor nuclei, TRPV4-IR was seen in vertical processes of Müller glial cells (see also Fig. $2 M$ for Müller cell signals in the ipl).

We also analyzed a transgenic mouse in which GFP was driven by the entire promoter of the mouse Trpv4 gene. The $50 \mathrm{kDa}$ Trpv4 gene was centered within the $200 \mathrm{kDa}$ GFP insert present in a BAC (see Materials and Methods). Using an antibody against GFP, retinal immunostaining was confined to cell bodies within the ganglion cell layer, although additional staining was noted in retinal blood vessels, in keeping with well established vascularendothelial TRPV4 expression (Hartmannsgruber et al., 2007; Mendoza et al., 2010). When the retina was stained with antiGFP, the marker was detected in cell bodies of the ganglion cell layer (Fig. 2C). Confirming that reporter gene expression was faithful to the targeted gene, $\operatorname{Tr} p v 4$, GFP-IR was absent in wildtype mouse retina (not illustrated).

To probe whether TRPV4-IR is associated primarily or exclusively with ganglion cells, we immunostained the retina for Brn3a (also called POU4f1), a transcription factor found almost exclusively in developing (Liu et al., 2000) and mature ganglion cells (Nadal-Nicolás et al., 2009). We found that TRPV4-IR colocalized with that of Brn3a in ganglion cell perikarya and dendrites (Fig. 2D, arrow). Prominent additional TRPV4-IR was found within ganglion cell axon bundles in the optic fiber layer (ofl) (Fig. 2D), and also was abundant within the optic nerve head (Fig. $2 \mathrm{H}$ ) and the laminar region of the optic nerve (Fig. 2I). The nearly universal distribution of Brn3a-IR in mouse retinal ganglion cells, together with the finding that Brn3a-IR and TRPV4-IR almost invariably colocalize, indicates that TRPV4 protein is distributed among a large fraction of mouse retinal ganglion cells.

A second marker for ganglion cells was provided by a construct in which GFP was linked to the promoter of Thyl, a ganglion cell-specific protein (see Materials and Methods). GFP-IR and TRPV4-IR colocalize in perikarya and dendrites of RGCs (Fig. 2E) and in displaced ganglion cell perikarya (Fig. $2 L$ ). Finally, immunostaining with an SMI-32 antibody that labels intermediate filaments in somata and axonal processes of wide-field $\alpha$ RGCs colocalized with TRPV4-IR processes in the ofl entering the optic nerve head (Fig. $2 K$ ).

TRPV4-IR is weak or absent in retinal amacrine cells

Approximately $50 \%$ of the cells within the ganglion cell layer in rodent retinas are displaced amacrine neurons rather than ganglion cells, whereas a subset of cells in the proximal inl belong to displaced RGCs (Perry and Walker, 1980; Jeon et al., 1998). To probe possible colocalization of TRPV4-IR with amacrine cells, we immunostained the retina with an antibody against choline acetyltransferase, a marker for starburst amacrine cells (Fig. 2G), and with glutamic acid decarboxylase 65 (GAD-65), a marker for 

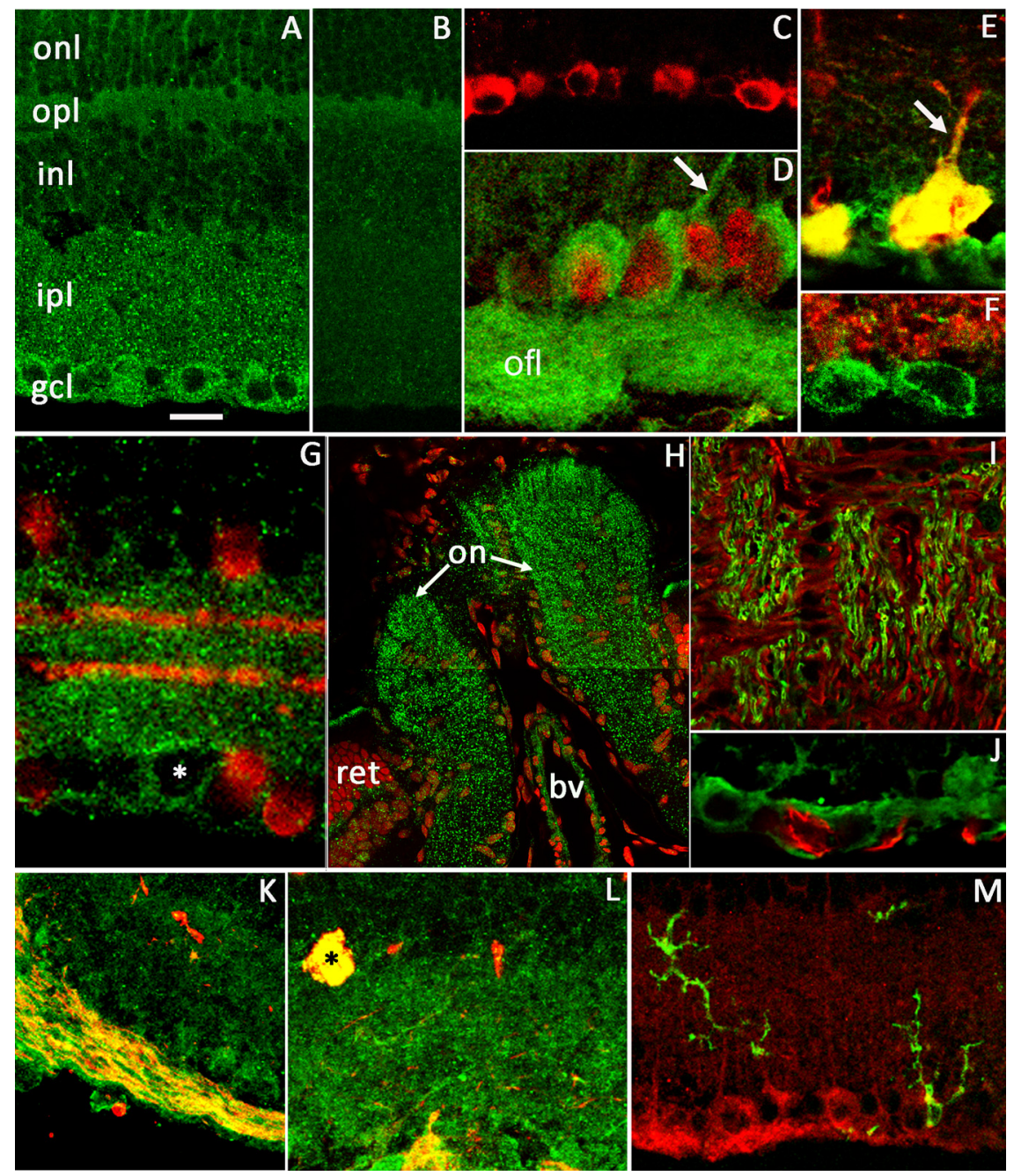

Figure 2. TRPV4 immunoreactivity in the mouse retina. $\boldsymbol{A}$, Vertical section of mouse retina. TRPV4-IR is expressed in ganglion cell somata and throughout the ipl. TRPV-IR in the onl is expressed in vertical fibers of Müller glial cells which run through this layer. Scale bars: (in $\boldsymbol{A}) \boldsymbol{A}-\boldsymbol{C}, \boldsymbol{I}-\boldsymbol{M}, 20 \mu \mathrm{m}$; (in $\boldsymbol{A}) \boldsymbol{D}-\mathbf{G}, 15 \mu \mathrm{m}$; (in $\boldsymbol{A}) \boldsymbol{H}, 40 \mu \mathrm{m}$. $\boldsymbol{B}$, Absence of specific TRPV4 immunostaining in the retina of a TRPV4-null mouse. C, Transgenic retina produced by recombineering with copGFP sequence inserted cis- to the Trpv4 promoter (see Materials and Methods). GFP (red) is localized to cytosol of retinal ganglion cells. D, Colocalization of TRPV4-IR (green) and Brn3a-IR (red), a ganglion cell-specific protein in ganglion cell somata. Additional TRPV4-IR is seen in a ganglion cell dendrite (arrow) and in the ofl, which contains ganglion cell axons en route to the optic nerve. $\boldsymbol{E}$, Colocalization of TRPV4-IR (green) and GFP-IR (red) in a mouse line in which CFP was coupled to the promoter of Thy-1, a ganglion cell specific protein. Colocalization is seen both in the ganglion cell bodies (yellow) and in a ganglion cell dendrite (arrow). F, TRPV4-IR in ganglion cell bodies (green) does not colocalize with GAD-65-IR (red). G, TRPV4-IR (green) does not colocalize with ChAT-IR (red) seen in cell bodies of starburst amacrine cells (red) and in two discrete horizontal bands in the ipl. A labeled ganglion cell body is indicated by an asterisk. $\boldsymbol{H}$, Montage of the opticnerve (on) showing immunolabeling of optic nerve fibers with TRPV4 (green). Cell nuclei are stained with Sytox Orange. bv, Blood vessel; ret, retina. I, Higher-magnification view of the optic nerve, illustrating that TRPV4-IR (green) is confined to optic nerve axons, whereas astrocytes labeled with a GFAP antibody (red) do not colocalize with TRPV4-IR.J, Vertical section of retina illustrating ganglion cells labeled with the TRPV4 antibody. GFAP-IR-labeled astrocytes in the of (red) do not colocalize with TRPV4. $\boldsymbol{K}$, Vertical section of retina illustrating boundary between ofl and on. TRPV4-IR ( $g r e e n$ ) is seen within these layers, and it colocalizes with intermediate filament immunoreactivity (SMI-32; red). The merged portions appear yellow. L, Vertical section of retina illustrating a displaced ganglion cell (asterisk) at the inl/ipl border that colocalizes with TRPV4-ir (green) and GFP-IR in mice in which GFP is coupled to the Thy-1 promoter. Amacrine cell bodies at this same interface do not label with either antibody. A labeled ganglion cell (yellow profile) in the gd is seen at bottom. $\boldsymbol{M}$, Vertical section of retina labeled with antibodies against TRPV4 (red) and Alexa Fluor-conjugated rat anti-mouse CD11B (green), a microglial-specific antibody. TRPV4-IR is seen in ganglion cell bodies and Müller glial cell processes. Two labeled microglial cells do not colocalize with TRPV4-IR.

GABAergic amacrine cells (Figs. $2 F, 3 A$ ) that constitute a substantial fraction of displaced amacrine cells in the RGC layer (May et al., 2007). These tests revealed no colocalization of TRPV4-IR with ChAT-IR cells. Moreover, no colocalization with the dopaminergic amacrine cell marker tyrosine hydroxylase was observed (data not shown). A total of $4.6 \%$ of cells that labeled with the GABAergic marker GAD-65 stained with the TRPV4 antibody; however, the intensity of

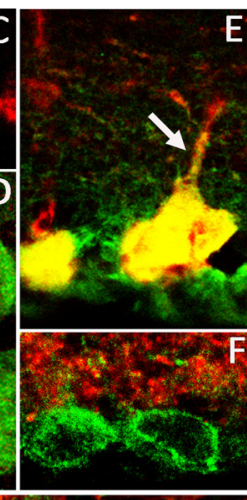

TRPV4-IR signals in this subset of cells was always significantly weaker compared with Brn3a-IR cells. Occasionally, a Brn3a-IR or SMI-32-IR cell body was detected in the inl. These perikarya were always TRPV4 immunopositive (Fig. $2 L$ ). Collectively, these data indicate that TRPV4-IR is associated with mouse retinal ganglion cells and may be localized to a small subset of GABAergic amacrine cells. Within the mouse ganglion cell, TRPV4-IR is associated principally with the perikaryon and the axon, but at least some ganglion cell dendrites also express TRPV4 (Fig. 2D, F, arrow).

\section{TRPV4-IR in retinal glial cells}

Detailed inspection of TRPV4-IR in the inner and outer retina revealed radial immunopositive processes that correspond to Müller macroglia (Fig. 2M). To assess TRPV4 expression in astrocytes, sections from the retina and at the glial lamina at the optic nerve head were colabeled with the glial fibrillar acidic protein (GFAP) antibody. No colocalization was observed, as TRPV4 and GFAP signals in the retina and the glial lamina appeared to label two distinct populations (Fig. 2I,J). Likewise, costaining with the microglia-specific Mac1/CD11b antibody showed no overlap with TRPV4 (Fig. 2M) but showed staining in the radial processes emanating from the inner limiting membrane that may correspond to Müller macroglia. These data indicate that in the wild-type mouse retina TRPV4 is excluded from astrocytes and microglia but is expressed in Müller cells.

\section{Physiological tests of TRPV4 function in mouse retina}

Identification of RGCs in short-term culture

In retinal neurons isolated into shortterm culture (see Materials and Methods) GABAergic neurons, identified by GAD65-IR, were invariably distinct from cells showing TRPV4-IR (Fig. 3Ai-iii). It was also apparent that TRPV4-IR cells were larger than those immunostained by GAD-65 (Fig. 3Aiii,B). Another test of ganglion cell identity in cultured neurons was immunoreactivity to an anti-Brn3a antibody (Fig. 4Ai). Brn3a-IR cells were invariably immunopositive for TRPV4, whereas photoreceptor and presumed amacrine perikarya were not (Figs. 2-4).

We extended measures of cell diameters to Brna3a-IR and Thyl:CFP neurons in culture and compared their dimensions to those of Brna3a-IR neurons in retinal slices; the data are summarized in Figure $3 \mathrm{~B}$. Diameters of dissociated Brn3a-IR cells were 9.1 $\pm 1.5 \mu \mathrm{m}(N=74$; mean $\pm \mathrm{SD})$, not significantly different from $10.2 \pm 1.8 \mu \mathrm{m}(N=58)$ in dissociated Thy1:CFP cells and $10.3 \pm 2.0 \mu \mathrm{m}$ in Brn3a-IR cells in 

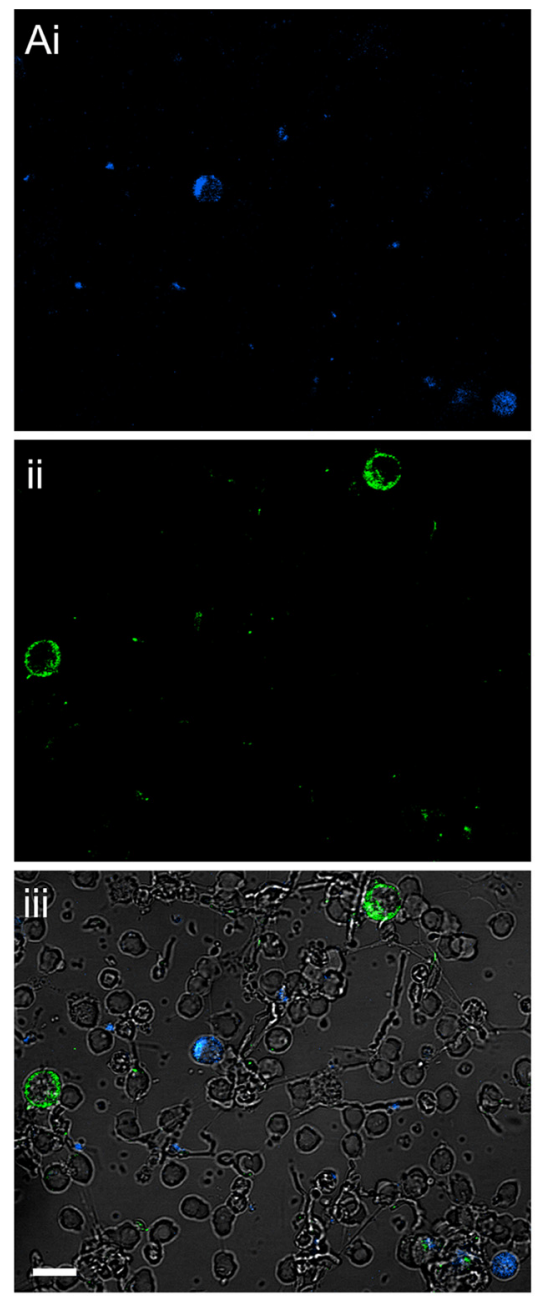

B

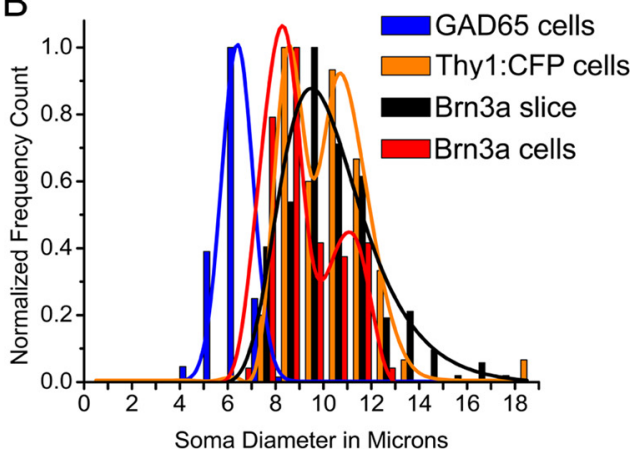

Figure 3. TRPV4 is not expressed in amacrine cells. $A$, Double labeling for GAD-65-IR ( $A$ i; blue), TRPV-IR (Aii; green), and superimposed transmitted image (Aiii) shows that TRPV4 signals are expressed in a population of cells that is distinct from GABAergic amacrine cells. Scale bar, $10 \mu \mathrm{m}$. $\boldsymbol{B}$, The distribution of cell diameters from dissociated RGCs that were (Brn3a) or were not (Thy1:CFP +) fixed, overlaps with Brn3a-IR somata from retinal sections. Little overlap in diameter distributions is seen between the RGC cohorts and GABAergic cells.

retinal sections $(N=201)(p>0.05$, Dunn's multiplecomparisons test) (Fig. 3B). The distribution of cell diameters confirms that the vast majority of ganglion cells have diameters $\geq 8 \mu \mathrm{m}$, whereas GABAergic amacrines are almost invariably $<8$ $\mu \mathrm{m}$. Moreover, the size distributions of ganglion cell diameters based on the different criteria illustrated in Figure $3 B$ are coextensive. Thus, our selection of a neuron for physiological study initially was made on the basis of cell diameter. In a few cases, we recorded $\mathrm{Ca}^{2+}$ signals from cyan fluorescent protein (CFP)- positive RGCs isolated from Thyl:CFP retinas, and in other experiments we confirmed the identity of TRPV4 agonist-responding cells by immunostaining the test cells for TRPV4-IR and Brn3a-IR following drug exposure.

\section{TRPV4 agonists induce an increase in $\left[\mathrm{Ca}^{2+}\right]_{R G C}$}

Once a putative RGC was selected for experimentation, we first tested the ability of glutamate to evoke an increase in $\left[\mathrm{Ca}^{2+}\right]_{\mathrm{i}}$. RGCs have ionotropic glutamate receptors that result in ganglion cell depolarization and calcium entry, so a vigorous response to glutamate is a good initial test of RGC viability. To evaluate functional expression of TRPV4 channels in the retina, we measured calcium concentrations in dissociated RGCs before and after TRPV4 agonist application, using ratiometric $\mathrm{Ca}^{2+}$ imaging of RGCs loaded with Fura-2 AM.

On average, glutamate $(100 \mu \mathrm{M})$ evoked a $\left[\mathrm{Ca}^{2+}\right]_{\mathrm{RGC}}$ increase of $490 \pm 25 \mathrm{~nm}$ (mean $\pm \mathrm{SE})$ over a baseline of $45 \pm 2 \mathrm{~nm}(N=$ 216 ; $p<0.0001$, Wilcoxon matched-pairs signed ranks test). Endogenous TRPV 4 channels in dissociated neurons were activated with the following two selective TRPV4 activators: the synthetic phorbol ester $4 \alpha$-phorbol 12-myristate13-acetate (didecanoate; $4 \alpha$-PDD), which directly binds to the transmembrane region of the protein (Watanabe et al., 2002; Vriens et al., 2007; Loukin et al., 2010a); and the recently characterized high-affinity agonist GSK1016790A (hereafter GSK; EC $50 \sim 1-10 \mathrm{nM}$ ) (Thorneloe et al., 2008; Willette et al., 2008). Figure $4 B$ illustrates a simultaneous recording from two putative RGCs that responded to glutamate and the two TRPV4 agonists (GSK, $25 \mathrm{~nm} ; 4 \alpha$-PDD, $30 \mu \mathrm{M}$ ). At 25 and $100 \mathrm{~nm}$, GSK elicited robust $\left[\mathrm{Ca}^{2+}\right]_{\mathrm{i}}$ increases in 40.5 and $47.2 \%$ of glutamate-responding cells $(N=10$ and 4 experiments), respectively (Figs. 4, 5, 6). In the continued presence of TRPV4 activators, $\left[\mathrm{Ca}^{2+}\right]_{\mathbf{i}}$ levels typically exhibited a decline, consistent with desensitization of the channel (Fig. $4 B$ ).

Mean $\left[\mathrm{Ca}^{2+}\right]_{\mathrm{RGC}}$ elevation induced by $25 \mathrm{nM}$ GSK was $381 \pm$ 41 nM over the $\left[\mathrm{Ca}^{2+}\right]_{\text {RGC }}$ baseline (Fig. $\left.4 G\right)(N=23 ; p<0.0001$, Wilcoxon matched-pairs signed-ranks test), whereas $100 \mathrm{~nm}$ GSK elevated $\left[\mathrm{Ca}^{2+}\right]_{\mathrm{i}}$ by $600 \pm 210 \mathrm{~nm}(N=9 ; p<0.004$, Wilcoxon matched-pairs signed-ranks test). In 15 putative RGCs, $4 \alpha$-PDD $(30 \mu \mathrm{M})$ increased the $340 / 380$ ratio from $0.464 \pm 0.029$ to $1.430 \pm 0.097$ ( $p<0.0001$, paired $t$ test) (Fig. $4 B, E)$. When cells that had been stimulated with TRPV4 activators were subsequently immunostained for TRPV4 and Brn3a, the two markers labeled responding cells (Fig. $4 D$, arrowhead) but not GSK-insensitive cells. The average diameter of cells that responded to TRPV4 agonists was $8.9 \pm 1.0 \mu \mathrm{m}$, not significantly different from diameters of Thy1:CFP and Brn3a-IR dissociated cells $(p>0.05)$ (Figs. $3 B, 4 H)$. The very substantial overlap of these two populations, responders and immunoreactive cells, provides more evidence that at least the great majority of cells selected for physiological study were retinal ganglion cells. Our data would also suggest that a subset of largediameter RGCs may not express TRPV4 (Fig. 3B) or respond to TRPV4 agonists (Fig. 4G).

Ruthenium Red and lanthanides are nonselective TRP channel blockers that also antagonize activation of TRPV4 channels (Liedtke et al., 2000; Strotmann et al., 2000; Watanabe et al., 2002). $\left[\mathrm{Ca}^{2+}\right]_{\mathbf{i}}$ responses to GSK and $4 \alpha$-PDD were suppressed by Ruthenium Red (10 $\mu \mathrm{m} ; N=85)$ (Fig. $4 D, E, G)$. The antagonist decreased the amplitude of GSK-evoked $\left[\mathrm{Ca}^{2+}\right]_{\mathrm{i}}$ responses from $341 \pm 41 \mathrm{~nm}(N=23)$ to $139 \pm 22 \mathrm{~nm}$ (Fig. $4 G)(N=16$; $p=0.0001$, Mann-Whitney test $)$ and reduced the percentage of cells responding to GSK from $40.5 \pm 6.7(N=10)$ to $16.9 \pm 4.2 \%$ $(N=4 ; p=0.026$, unpaired $t$ test $)$. In the phorbol ester- 

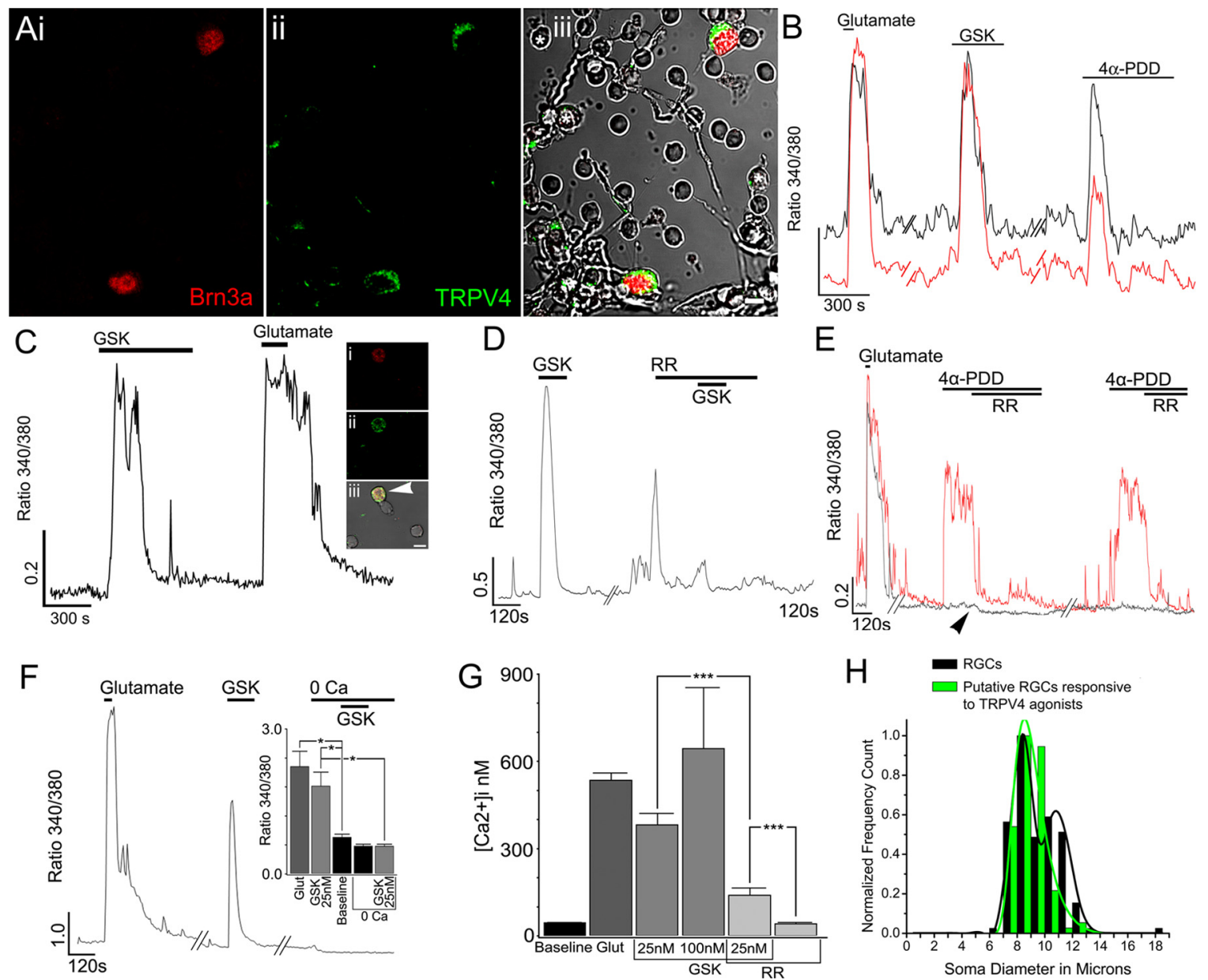

Figure 4. TRPV4 agonists selectively elevate $\left[\mathrm{Ca}^{2+}\right]_{\mathrm{i}}$ in mouse RGCS. A, Brn3a-IR (Ai) and TRPV4 (Aii) colocalize in two RGCs (Aiii). TRPV4-IR is absent from putative amacrine somata (asterisks). Scale bar, $5 \mu \mathrm{m}$. B, Application of GSK1016790A or $4 \alpha$-PDD induces $\mathrm{Ca}^{2+}$ influx into two simultaneously recorded RGCs. C, Four retinal cells immunostained for Brn3a and TRPV4. The cell that responded to GSK with $\left[\mathrm{Ca}^{2+}\right]_{\mathrm{i}}$ increase, but not nonresponders, exhibited colocalization of Brn3a (i) and TRPV4 (ii) immunoreactivity after fixation and immunolabeling. iiii, Transmitted image with superimposed TRPV4 and Brn3a signals. Scale bar, $5 \mu \mathrm{m}$. D, GSK-induced $\left[\mathrm{Ca}^{2+}\right]_{\mathrm{i}}$ responses are antagonized by Ruthenium Red (RR). $\boldsymbol{E}$, Simultaneous recording from a putative RGC (red trace) and a putative amacrine cell (black trace) stimulated with $4 \alpha$-PDD. Ruthenium Red antagonizes TRPV4 agonist responses evoked in the RGC. The amacrine cell is unresponsive to $4 \alpha$-PDD; however, Ruthenium Red slightly reduced baseline $\left[\mathrm{Ca}^{2+}\right]_{\mathrm{i}}$ in this cell (arrowhead). $\boldsymbol{F}$, Putative RGC, stimulated with GSK in the presence and absence of extracellular $\mathrm{Ca}^{2+}$. Extracellular calcium is required for agonist-evoked $\left[\mathrm{Ca}^{2+}\right]_{\mathrm{i}}$ elevations. Inset, Comparison of $\left[\mathrm{Ca}^{2+}\right]_{\mathrm{i}}$ for glutamate, GSK, baseline levels in $\mathrm{Ca}^{2+}$-free saline and in $0 \mathrm{Ca}^{2+}+25 \mathrm{~nm} \mathrm{GSK}$. G, Cumulative $\left[\mathrm{Ca}^{2+}\right]_{\mathrm{i}}$ for calibrated RGC

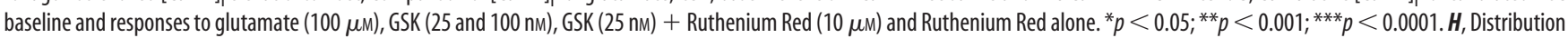
of cell diameters for dissociated RGCs (Thy1:CFP and Brn3-IR cells; black trace) and putative RGCs that responded to TRPV4 agonists (green trace).

insensitive cell depicted in Figure 4E, Ruthenium Red by itself lowered baseline $\left[\mathrm{Ca}^{2+}\right]_{\mathbf{i}}$ (arrowhead), indicating suppression of tonic $\mathrm{Ca}^{2+}$ influx through TRP-like channels. On average, $\mathrm{Ru}-$ thenium Red decreased baseline $\left[\mathrm{Ca}^{2+}\right]_{\mathrm{i}}$ from $50 \pm 3 \mathrm{~nm}$ to $47 \pm$ $4 \mathrm{~nm}(N=133 ; p=0.0003$, Wilcoxon matched-pairs signedranks test).

The rise in intracellular $\mathrm{Ca}^{2+}$ induced by exposure to GSK depends on extracellular $\mathrm{Ca}^{2+}$. Figure $4 F$ illustrates that a test cell shows normal increases in $\left[\mathrm{Ca}^{2+}\right]_{\mathrm{i}}$ in responses to GSK in $2 \mathrm{mM}\left[\mathrm{Ca}^{2+}\right]_{\mathrm{o}}$, but this increase was abolished in zero extracellular $\left[\mathrm{Ca}^{2+}\right]_{\mathrm{o}}(N=8 ; p=0.78$, paired $t$ test $)$. The mean fluorescence changes induced by glutamate or GSK in normal versus zero extracellular $\mathrm{Ca}^{2+}$ are summarized in the inset to Figure $4 F$.

Ligand-evoked $\left[\mathrm{Ca}^{2+}\right]_{\mathbf{i}}$ increases in mouse RGCs can be augmented by secondary contributions from voltage-operated $\mathrm{Ca}^{2+}$ channels (Hartwick et al., 2008). We therefore investigated whether the response to $25 \mathrm{~nm}$ GSK was affected by suppression of voltage-operated $\mathrm{Ca}^{2+}$ entry. In the presence of the nonselective voltage-gated calcium channel antagonist cadmium $\left(\mathrm{Cd}^{2+}\right.$;
$100 \mu \mathrm{M})$, high $\mathrm{KCl}(30 \mathrm{mM})$-evoked $\left[\mathrm{Ca}^{2+}\right]_{\mathbf{i}}$ increases were blocked ( $N=5$; data not shown). Nonetheless, GSK elevated $\left[\mathrm{Ca}^{2+}\right]_{\mathbf{i}}$ to $355 \pm 110 \mathrm{nM}$ in $\mathrm{Cd}^{2+}$-containing saline $(N=6)$, a value not significantly different from responses to the agonist alone ( $p>0.89$, Mann-Whitney test). $\mathrm{Cd}^{2+}$ had no significant effect on the percentage of GSK-responding cells $(31.3 \pm 5.2 \%$; $p>0.36$, unpaired $t$ test).

A representation of glutamate- and GSK-evoked $\left[\mathrm{Ca}^{2+}\right]_{\mathbf{i}}$ elevations in a presumed RGC is represented graphically in Figure 5. This cell was proximal to a perikaryon from a presumed rod photoreceptor (Fig. 5A). A 60 s exposure to a saturating concentration of the neurotransmitter $(100 \mu \mathrm{M})$ and sustained (5 min) exposure to GSK (25 nM) evoked an increase in global free $\left[\mathrm{Ca}^{2+}\right]_{\mathbf{i}}$ across the RGC cytosol, with superimposed local $\left[\mathrm{Ca}^{2+}\right]_{\mathbf{i}}$ elevations. The response to the TRPV4 agonist desensitized during continued exposure (Fig. $5 \mathrm{~J}, \mathrm{~K}$ ) in contrast to responses to sustained $\left[\mathrm{Ca}^{2+}\right]_{i}$ elevations that were observed during 3-5 min exposures to glutamate. No changes in $\left[\mathrm{Ca}^{2+}\right]_{\mathbf{i}}$ were observed in the simultaneously recorded rod perikaryon. 

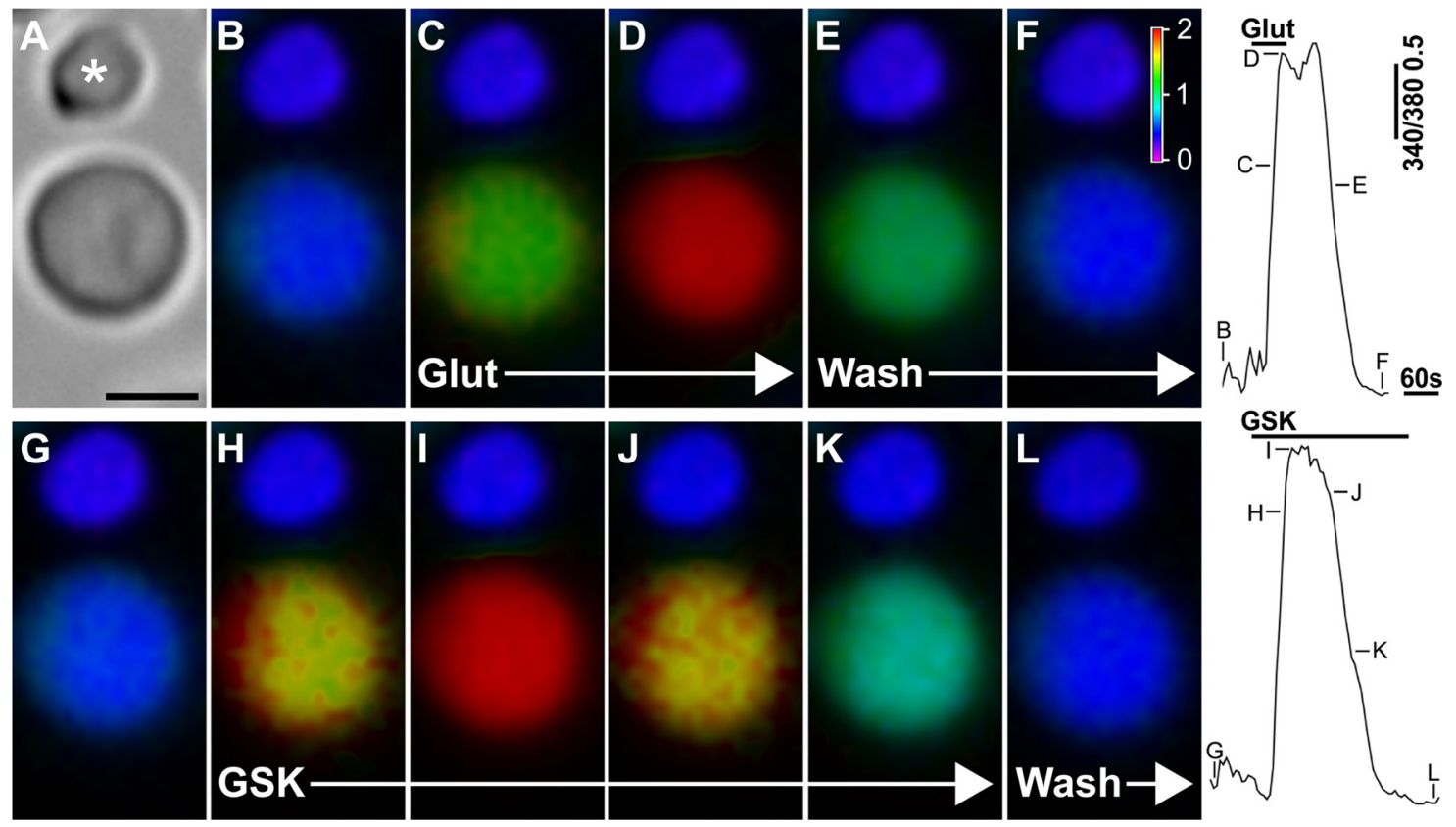

Figure 5. GSK-induced $\left[\mathrm{Ca}^{2+}\right]_{\mathrm{i}}$ dynamics in an RGC. $A$, Transmitted image of a putative RGC and rod photoreceptor. Scale bar, $5 \mu \mathrm{m}$. The temporal progression of upper and lower image sequences is illustrated by the adjacent traces. $\boldsymbol{B}, \boldsymbol{G}$, Unstimulated cells perfused with control saline. $\boldsymbol{C}, \boldsymbol{D}$, The $\mathrm{RGC}$ responds to the bath application of glutamate with a large increase in $\left[C{ }^{2+}\right]_{\mathrm{j}} \cdot \boldsymbol{E}$, $\boldsymbol{F}$, Washout. Scale bar: $\boldsymbol{F}, 340 / 380$ ratio level. $\boldsymbol{H}-\boldsymbol{K}$, Application of GSK transiently elevates $\left[\mathrm{Ca}^{2+}\right]_{\mathrm{i}}$ in the RGC but not the rod. $\boldsymbol{J}, \boldsymbol{K},\left[\mathrm{Ca}^{2+}\right]_{\mathrm{i}}$ levels decline in the continued presence of GSK. $\boldsymbol{L}$, Washout.

Hypotonic stimuli evoke changes in cytosolic $\left[\mathrm{Ca}^{2+}\right]_{\mathrm{i}}$

TRPV4 was originally identified as a plasma membrane channel activated by hypotonic cell swelling (Liedtke et al., 2000; Strotmann et al., 2000; Watanabe et al., 2002; Vriens et al., 2004; Loukin et al., 2010a). A decrease in extracellular osmolarity induces $\mathrm{Ca}^{2+}$ influx through TRPV4 channels (Güler et al., 2002; Liedtke and Friedman, 2003; Raoux et al., 2007; Phan et al., 2009). To determine whether hypotonicity modulates $\left[\mathrm{Ca}^{2+}\right]_{\mathrm{RGCs}}$, cells were exposed to saline solutions with osmolarity reduced from 280 to 190 mOsm. As illustrated in Figure 6A for an RGC loaded with the $\mathrm{Ca}^{2+}$-insensitive cell-volume indicator dye calcein AM, a reduction in osmolarity of the superfusing saline from 280 to $192 \mathrm{mOsm}$ saline evoked sustained swelling of the cell. The resulting increase in cell volume was detected as a decrease in the intensity of calcein fluorescence (Fig. 6 A, green trace). In contrast to hypotonic stimuli, no change in intracellular volume was observed during exposure to $100 \mu \mathrm{m}$ glutamate.

Cell swelling was accompanied by tonicity-dependent elevations in $\left[\mathrm{Ca}^{2+}\right]_{\mathrm{i}}$. The $190-195 \mathrm{mOsm}$ saline evoked an average $\left[\mathrm{Ca}^{2+}\right]_{\mathbf{i}}$ increase of $439 \pm 59 \mathrm{~nm}(N=48 ; p<0.0001)$ (Fig. 6) in $72 \pm 7 \%$ of putative RGCs. During continued stretch, $\left[\mathrm{Ca}^{2+}\right]_{\mathrm{i}}$ levels gradually returned to control levels, indicating desensitization of the mechanosensing mechanism (Fig. 6). The diameters of cells that responded to hypotonic stimulation with $\left[\mathrm{Ca}^{2+}\right]_{\mathrm{i}}$ increases $(8.7 \pm 1 \mu \mathrm{m} ; N=126)$ were not significantly different from diameters of dissociated Brn3a-immunopositive cells $(9.1 \pm 1.5 \mu \mathrm{m} ; p>0.05 ; N=74)$ (Fig. 6E). Swelling-mediated $\left[\mathrm{Ca}^{2+}\right]_{\mathbf{i}}$ signals also were measured in the presence of gadolinium $\left(\mathrm{Gd}^{3+}\right)$, a universal antagonist of $\mathrm{Ca}^{2+}$-permeable TRP channels (including TRPV4) (Gustin et al., 1988; Becker et al., 2005). Gd ${ }^{3+}$ $(100 \mu \mathrm{M})$ reduced, from $72.1 \pm 6.7 \%(N=10)$ to $26.0 \pm 9.5 \%$ ( $N=3$ slides), the percentage of RGCs that responded to hypotonic stimulation with a $\left[\mathrm{Ca}^{2+}\right]_{\mathbf{i}}$ increase $(p<0.02$, unpaired $t$ test, Welch corrected) but had no effect on cell swelling, as indicated by unchanged calcein responses (Fig. 6A). Overall, the amplitude of hypotonic stretch-induced $\left[\mathrm{Ca}^{2+}\right]_{i}$ increases was reduced by $\mathrm{Gd}^{3+}$ to $261 \pm 42 \mathrm{~nm}(N=17 ; p<0.05$, MannWhitney test). Hypotonicity-induced $\left[\mathrm{Ca}^{2+}\right]_{\mathbf{i}}$ responses were suppressed by Ruthenium Red to $206 \pm 21 \mathrm{~nm}(N=22$; $p<$ 0.0001 , Mann-Whitney test) (Fig. 6C,D), and the percentage of RGCs responding to hypotonic stimulation in the presence of the antagonist decreased from $72.1 \pm 6.7 \%(N=10)$ to $16.9 \pm 4.2 \%$ ( $N=3$ slides; $p<0.005$, unpaired $t$ test, Welch corrected).

We asked whether hypotonically induced $\left[\mathrm{Ca}^{2+}\right]_{\mathrm{i}}$ elevations are mediated by TRPV4. $\left[\mathrm{Ca}^{2+}\right]_{\mathrm{i}}$ increases induced by TRPV4 agonists and membrane stretch typically desensitized with a time constant of several tens of seconds. Stimulation with GSK at the asymptotic end of the desensitized response elicited little or no change in $\left[\mathrm{Ca}^{2+}\right]_{\mathrm{i}}(169.9 \pm 66.2 \mathrm{nM})$, whereas significant $\left[\mathrm{Ca}^{2+}\right]_{\mathrm{i}}$ increases $(524.0 \pm 63.8 \mathrm{nM})$ were measured following washout with isotonic saline (Fig. $6 G)(N=14 ; p<0.002$, Wilcoxon matched-pairs signed-ranks test). Of $84.4 \pm 4.6 \%$ putative RGCs that responded to hypotonic stimuli in this experiment, $2.0 \pm 0.7 \%$ exhibited a response to GSK during membrane stretch, significantly less than the $51.7 \pm 7 \%$ that responded to GSK alone ( $N=3$ slides, 14 cells; $p<0.05$, paired $t$ test). To confirm that hypotonic cell swelling evoked $\mathrm{Ca}^{2+}$ influx from the extracellular space, cells were challenged with $\mathrm{Ca}^{2+}$-free saline. RGCs responding to hypotonic stimulation in $2 \mathrm{mM} \mathrm{Ca}^{2+}$-containing saline with $\left[\mathrm{Ca}^{2+}\right]_{\mathbf{i}}$ elevations displayed no change in $\left[\mathrm{Ca}^{2+}\right]_{\mathrm{i}}$ in $\mathrm{Ca}^{2+}$-free hypotonic saline $(N=$ 0/14) (Fig. 6D). Thus, stretch-induced $\left[\mathrm{Ca}^{2+}\right]_{i}$ elevations in RGCs primarily depend on entry of extracellular $\mathrm{Ca}^{2+}$ rather than on release from intracellular stores. Together, these data indicate that RGCs express an osmosensitive channel that exhibits the pharmacological profile of TRPV4.

GSK-responding RGCs constituted a subset of the total hypotonicity-sensitive cell cohort, possibly indicating the expression of other volume increase-sensitive channels within RGCs. We therefore tested for functional expression of TRPV1, another vanilloid TRP channel that has been associated with pressuresensitive $\left[\mathrm{Ca}^{2+}\right]_{\mathbf{i}}$ responses in RGCs (Sappington et al., 2009). Under our experimental conditions, the TRPV1 agonist capsai- 


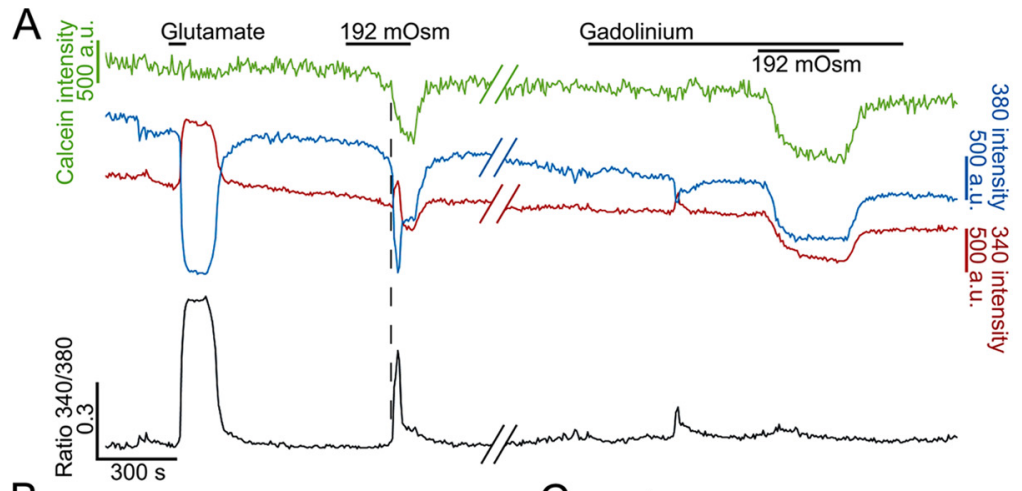

$\mathrm{B}$
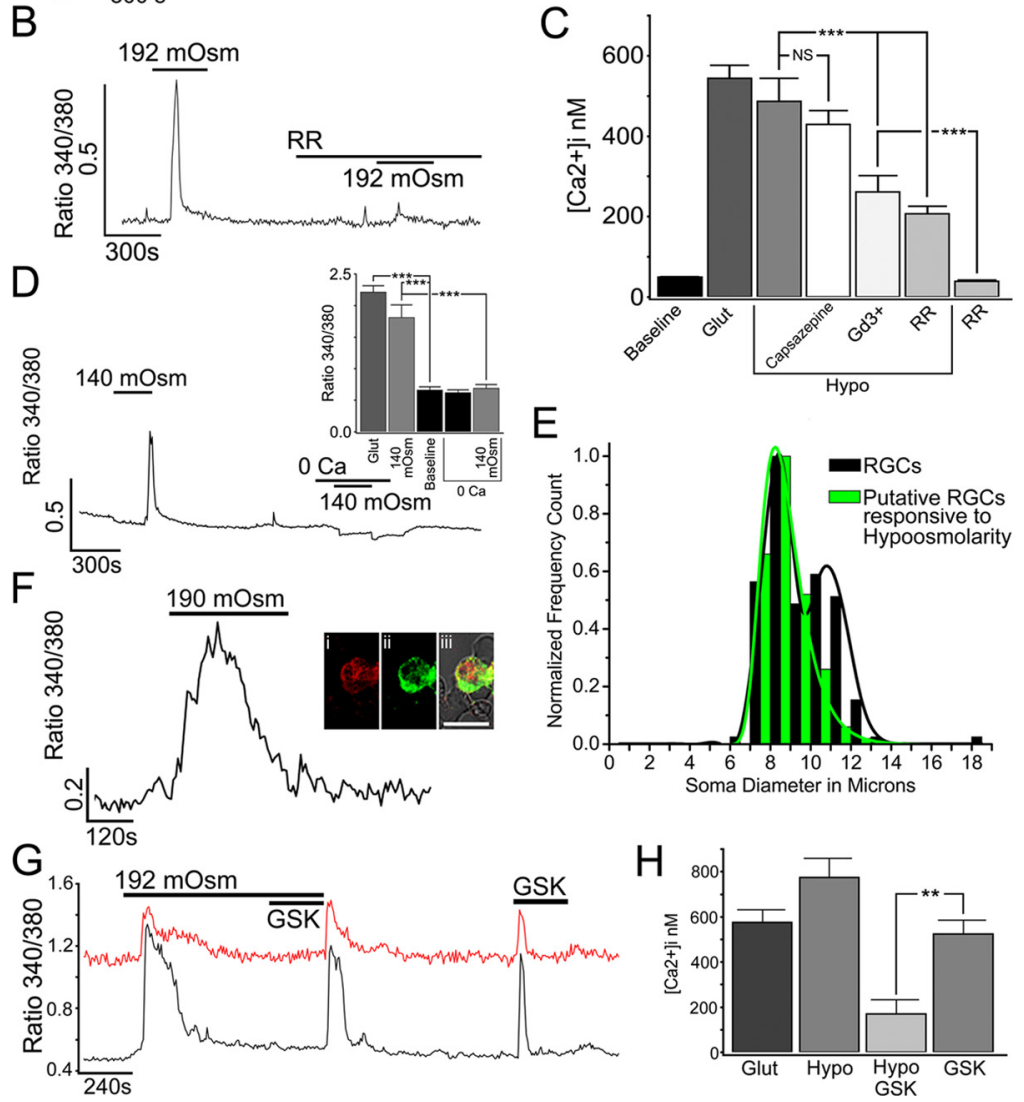

Figure 6. Cell stretch elevates $\left[\mathrm{Ca}^{2+}\right]_{\mathrm{RGC}} \cdot \boldsymbol{A}$, Simultaneous recording of RGC volume (calcein, green trace), $340 \mathrm{~nm}$ (red trace), $380 \mathrm{~nm}$ (blue trace) intensities, and $\left[\mathrm{Ca}^{2+}\right]_{\mathrm{i}}$ (fura-2 ratio, black trace). An increase in $\mathrm{RGC}$ volume was indicated by a drop in calcein fluorescence intensity during hypotonic stimulation (decreased osmolarity in superfusing saline from 280 to $192 \mathrm{m0sm}$ ). Glutamate stimulation increased $\left[\mathrm{Ca}^{2+}\right]_{\mathrm{i}}$ but evoked no change in the calcein signal. The increase in $\left[\mathrm{Ca}^{2+}\right]_{\mathrm{i}}$ induced by hypotonic stimulation was antagonized by $\mathrm{Gd}^{3+}$. B. Hypotonically induced $\left[\mathrm{Ca}^{2+}\right]_{\mathrm{i}}$ elevations are antagonized by Ruthenium Red. $\boldsymbol{C}$, Cumulative total for calibrated RGC $\left[\mathrm{Ca}^{2+}\right]_{\mathrm{i}}$ responses to glutamate $(100 \mu \mathrm{M})$, hypotonic stimulation (192 m0sm), and hypotonic stimulation in the presence of capsazepine, Ruthenium Red $(10 \mu \mathrm{M})$ or Gd $^{3+}(100 \mu \mathrm{M})$. NS, $p>0.05 ;{ }^{*} p<0.05 ;{ }^{* *} p<0.001$; ${ }^{* * *} p<0.0001 . D,\left[\mathrm{Ca}^{2+}\right]_{\mathrm{i}}$ trace from a GSK-sensitive RGC. Hypotonically evoked $\left[\mathrm{Ca}^{2+}\right]_{\mathrm{i}}$ increase requires $\mathrm{Ca}^{2+}$ influx from the extracellular space. Inset, Relative $\left[\mathrm{Ca}^{2+}\right]_{\text {; }}$ totals for control and hypotonically stimulated RGCs with and without the presence of extracellular calcium. $\boldsymbol{E}$, Distribution of cell diameters from dissociated RGCS (Thy1:CFP and Brn3-IR cells; black trace) and the hypotonicity-responding cohort (green trace). $\boldsymbol{F}$, Hypotonicity-responding cell, labeled with TRPV4 and Brn3a antibodies. Scale bar, $10 \mu \mathrm{m}$. G. Hypotonicity-induced membrane stretch occludes the response to GSK. The volume decrease following the hypotonic step was associated with a transient increase in $\left[\mathrm{Ca}^{2+}\right]_{\mathrm{i}} . \boldsymbol{H}$, Cumulative calibrated responses to glutamate $(100 \mu \mathrm{M})$, hypotonic stimulation (190-195 m0sm), GSK (25 nM) and GSK in the presence of hypotonic stretch shows a marked reduction in the amplitude of the TRPV4 agonist-evoked response during mechanical stimulation.

cin $(5-100 \mu \mathrm{M})$ did not induce a rise in $\left[\mathrm{Ca}^{2+}\right]_{\mathbf{i}}$ in acutely isolated mouse RGCs $(N>110)$. Moreover, the selective TRPV1 antagonist capsazepine $(5 \mu \mathrm{M})$ had no effect on the amplitude of hypotonic stretch-evoked increases ( $487 \pm 59 \mathrm{~nm}$ in controls; $N=48$ vs $429 \pm 48$ in the presence of capsazepine; $N=29$; $p=0.39$, Mann-Whitney test) (Fig. 6C) or the percentage of cells respond- ing to hypotonic stimulation $(N=2$; $62.0 \pm 14.9 \% ; p=0.62$, unpaired $t$ test $)$. These results argue against a significant role for TRPV1 signals in stretch-evoked $\mathrm{Ca}^{2+}$ signaling in mouse RGCs.

\section{TRPV4 agonists modulate RGC firing} Given that TRPV4 activation elevates $\left[\mathrm{Ca}^{2+}\right]$ in RGCs, we asked whether the depolarizing cation influx through the TRPV4 channel modulates RGC excitability. Intact retinas were isolated from the eye and positioned on MEAs, which allow recording of spontaneous spikes from many RGCs simultaneously (Rentería et al., 2006). Perfusion with the TRPV4 agonists $4 \alpha$-PDD ( $5 \mu \mathrm{M})$ or GSK (100 or $300 \mathrm{nM}$ ) evoked a transient increase in the frequency of spontaneous firing in a subset of recorded RGCs. The spike rates of three RGCs, in which typical increases in spiking after GSK application occurred, are shown in Figure 7A. For all recorded cells, the average firing rate during the first $3 \mathrm{~min}$ after drug application was compared with the preapplication frequency ( $4 \alpha$-PDD: $N=160$ RGCs from three retinas; GSK: $N=115$ RGCs from 4 retinas). Figure $7, B$ and $C$, shows the changes in cell firing evoked by each TRPV4 agonist as a percentage of the preapplication firing frequency. Each agonist evoked increased spike rates of twofold or more in a large percentage of the recorded RGCs (Fig. $7 B, C$, arrows) $(p<0.00001$ for $4 \alpha$-PDD; $p<0.02$ for GSK; Wilcoxon signed-rank test). The increase in spike rate during drug application was transient, exhibiting significant adaptation in the continued presence of drug (Fig. 7A). Displaced amacrine cells either do not spike (Zhou and Fain, 1996) or express few action potentials in response to depolarizing current injection (Ozaita et al., 2004). This suggests that the majority of cells responding to TRPV4 agonists were RGCs, although some nonresponders (5$10 \% /$ retina) may have been displaced amacrine cells. These experiments indicate that TRPV4 activation transiently increased RGC excitability and augmented RGC output from the retina.

\section{Sustained activation of TRPV4 channels is cytotoxic for RGCs}

We next considered whether extended stimulation with a TRPV4 agonist impacts the survival of acutely isolated RGCs. As shown previously (Otori et al., 1998; Hartwick et al., 2008), $1 \mathrm{~h}$ incubation with the AMPA/KA receptor agonist kainate $(10 \mu \mathrm{M})$ increased the number of TUNELpositive cells by $68 \pm 7 \%(N=305 ; p<0.0001$, Mann-Whitney $)$ (Fig. $8 B, D$ ), whereas RGCs exposed only to control saline supplemented with L15 showed little TUNEL signal (Fig. 8A,D). Exposure 
to GSK1016790A induced significant cell death, which was confined to cells with large somata ( $>6 \mu \mathrm{m}$, arrowheads). The $25 \mathrm{nM}$ GSK induced TUNEL-positive signals in $33 \pm 7 \%(N=1523 ; p=0.0002)$, and 100 nM GSK induced TUNEL labeling in $67 \pm$ $13 \%$ of presumed RGCs $(N=917 ; p<$ $0.0005)$. GSK had relatively little effect on signals in presumed photoreceptor perikarya (cell diameters, 3-5 $\mu \mathrm{m}$; arrows).

\section{Discussion}

This study provides anatomical, molecular, and physiological evidence that the polymodal pressure-sensitive TRPV4 ion channel participates in the transduction of hypotonic stimuli and contributes to $\mathrm{Ca}^{2+}$ dependent intracellular signaling and membrane excitability of mammalian RGCs. First, we have shown that the wild-type mouse retina expresses TRPV4 mRNA and protein. Second, we show that the TRPV4 protein is localized primarily in RGC somata and axons. Third, using $\mathrm{Ca}^{2+}$ imaging and MEA recording, we directly demonstrate that TRPV4 channels contribute to transmembrane $\mathrm{Ca}^{2+}$ flux and spike firing rates of RGCs. Finally, we show that pharmacological characteristics of hypotonicityinduced $\left[\mathrm{Ca}^{2+}\right]_{\mathbf{i}}$ increases in RGCs match the known pharmacology of TRPV4 and that sustained activation of this subtype of TRPV channels initiates cell death pathways in RGCs.

In the mouse retina, almost every cell identified with RGC-specific markers (Thyl:CFP; Thyl:GFP; Brn3a; SMI-32) was immunopositive for TRPV4, indicating that all identified RGC perikarya express TRPV4. TRPV4-IR was particularly prominent within RGC axons in the nerve fiber layer and the optic nerve head, both of which represent initial targets for deleterious effects of increased IOP. TRPV4 staining was excluded from amacrine, astrocytic, and microglial processes in the retina but was apparent in Müller cell processes. Our demonstration of the localization of the channels to RGCs suggests that retinal output neurons are capable of transducing mechanical, thermal, and/or osmotic stimuli.

\section{Functional role for TRPV4 in the retina}

Cell stretch induced by hypotonic swelling caused a marked increase in $\left[\mathrm{Ca}^{2+}\right]_{\mathrm{i}}$ of RGCs. Because the resting membrane potential of RGCs is within the operational range for inactivating and persistent $\mathrm{Na}^{+}$conductances $(\sim-60 \mathrm{mV}$ ) (Kim and Rieke, 2003; Hayashida and Ishida, 2004; Margolis et al., 2010), we postulate that sustained depolarization through stretch-sensitive cation-permeable channels will contribute to the excitability and dynamic range of RGC responses (Shibasaki et al., 2007) by countering, in a significant subset of RGCs, the tonic inhibition mediated by GABAergic and glycinergic amacrines. Consistent with this hypothesis, TRPV4 activators $4 \alpha$-PDD and GSK1016790A elevated $\left[\mathrm{Ca}^{2+}\right]_{\mathrm{i}}$ and caused $\mathrm{a}>100$-fold increase in the fre-
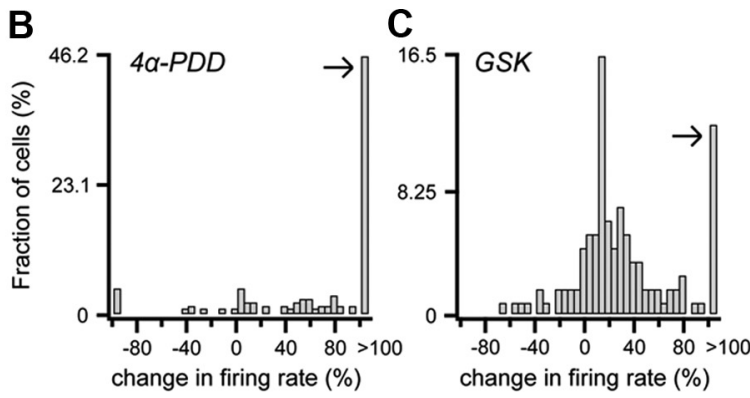

Figure 7. TRPV4 agonists transiently increase spontaneous firing rate of RGCs. $\boldsymbol{A}$, The spontaneous firing rates of three RGCs recorded on a multielectrode array are shown during the application of GSK at time 0 ( $300 \mathrm{~nm}$; black bar). The rate increased for $2-3$ min before returning to the initial baseline level during the continued presence of the drug for nearly all responsive cells. $B, A$ retreatment firing rate is shown for all cells recorded from three treated retinas. Cells with a rate double or higher in drug are 4 retinas). As in $\boldsymbol{B}$, cells with a spike rate double or higher during the initial period of drug exposure are combined in the rightmost bin ( $>100$; arrow), constituting $>12 \%$ of the recorded cells. The bias in the distribution to positive values reveals that most cells increased firing in response to GSK application.
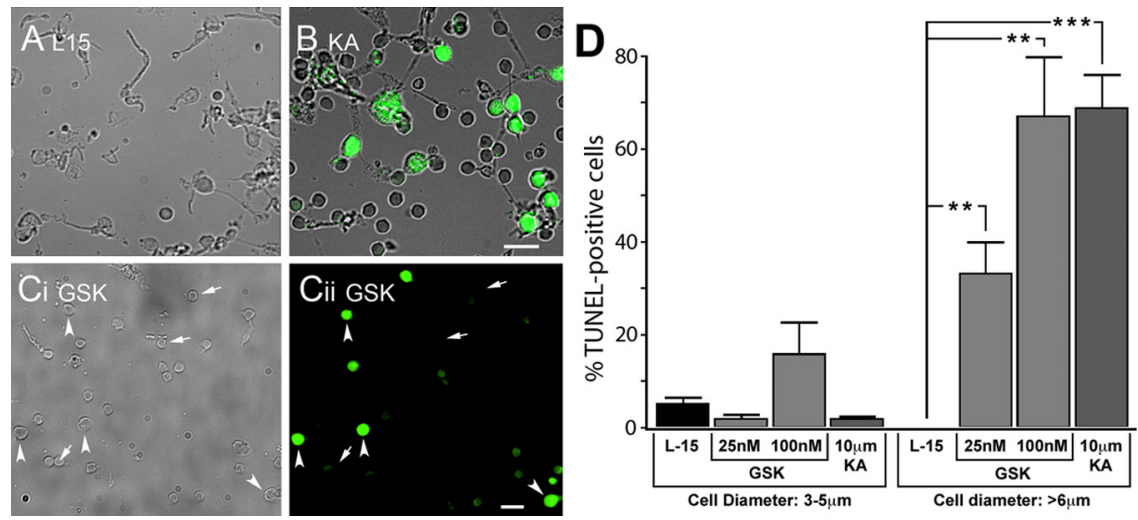

Figure 8. Exposure to TRPV4 agonist induces RGC apoptosis. $\boldsymbol{A}$, TUNEL (FITC) + transmitted image in control dissociated mouse

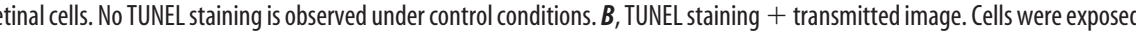
diameters 3-5 $\mu \mathrm{m}$ ) and putative RGCs (cell diameters $>6 \mu \mathrm{m}$ ) in L15 medium, $25 \mathrm{~nm} \mathrm{GSK,} 100 \mathrm{~nm}$ GSK, and KA in all experiments. ${ }^{* *} p<0.001$; ${ }^{* * *} p<0.0001$.

quency of spontaneous RGC spiking. While TRPV4 activation may also have influenced the increase in spiking through reciprocal neuroglial interactions (Newman, 2001), the comparable time courses of agonist-evoked $\left[\mathrm{Ca}^{2+}\right]_{\mathrm{i}}$ signals and spike firing argues for a predominant action on RGCs themselves. This finding may be relevant to entoptic physiology as it implicates TRPV4 channels in the perception of "pressure phosphenes" believed to originate in RGCs (Grüsser et al., 1989).

The effects of pharmacological and hypotonic stimulation observed in RGCs are consistent with properties of heterologously expressed and endogenous TRPV4 channels (Liedtke et al., 2000; Strotmann et al., 2000; Becker et al., 2005; Hartmannsgruber et al., 2007). Plasma membrane ion channels activated by an increase in cell volume were reported to be identical to TRPV4 agonist-sensitive channels with respect to $\mathrm{Ca}^{2+}$ permeability, rectification behavior, and permeability sequence of monovalent cations (Watanabe et al., 2002; Phan et al., 2009). While all Brn3a-IR and Thy1:CFP-positive cells labeled with TRPV4 antibodies, only a subset of dissociated putative RGCs was activated by hypotonic stimulation $(\sim 72 \%)$ or TRPV4 agonists $(\sim 16.7-$ 
95.8\%). We attribute the variability in stretch- and agonistinduced responses to the mechanical trauma associated with the dissociation protocol, which may have compromised a necessary step in TRPV4 activation. It is possible that, as suggested for other tissues (Raoux et al., 2007; Sharif-Naeini et al., 2008; AlessandriHaber et al., 2009), RGC plasma membranes have other volume increase-sensitive channels such as TRPC1, TRPV1, TRPV2, TREK-1, 2, or TRAAK (TWIK-related arachidonic acid-stimulated potassium channel) (Maingret et al., 1999; Reyes et al., 2000; Križaj, 2005; Leonelli et al., 2009). In particular, TRPV1 was recently implicated in mediating $\left[\mathrm{Ca}^{2+}\right]_{\mathbf{i}}$ increases and pressureinduced apoptotic cell death in cultured rat RGCs (Sappington et al., 2009). While no isoforms of TRPV1 are known to be affected by hypotonic stimulation (Liedtke et al., 2000; Strotmann et al., 2000; Loukin et al., 2009) and stimulation with specific TRPV1 agonists/antagonists failed to induce changes in $\left[\mathrm{Ca}^{2+}\right]_{\mathbf{i}}$ in acutely dissociated mouse RGCs under isotonic or hypotonic conditions, the difference between our study and that of Sappington et al. (2009) can be attributed in part to the dramatic upregulation of Trpv1 gene expression in cultured RGCs. We propose that TRPV4 is a necessary sensing/transducer protein that participates in the RGC response to volume increase, whereas TRPV1 may contribute to RGC excitability as well, once upregulated under certain culture conditions.

Consistent with a role in sensory transduction, TRPV4 is expressed in sensory neurons of dorsal root ganglia, in the trigeminal ganglion, and in hair cells (Liedtke et al., 2000; Alessandri-Haber et al., 2009). A major TRPV4 role in healthy RGCs may be to function as an osmoreceptor (Liedtke et al., 2003; Liedtke and Kim, 2005). The RGC cytosolic volume should be susceptible to local changes in tonicity that occur during the light response or retinal waves (Huang and Karwoski, 1992; Dmitriev et al., 1999). Swelling-induced increases in $\left[\mathrm{Ca}^{2+}\right]_{\mathrm{i}}$, but not swelling itself, were suppressed by $\mathrm{Gd}^{3+}$ and Ruthenium Red, two compounds that inhibit osmosensory transduction (Liedtke et al., 2003; Bourque, 2008). Activation of endogenous TRPV4 channels has been implicated in other mechanotransduction events including shear stress in vascular endothelia (Hartmannsgruber et al., 2007), stretch-induced integrin signaling (Thodeti et al., 2009), shear stress-mediated relaxation of endothelial cells (Mendoza et al., 2010), and viscous load-coupled ciliary activity in epithelial cells (Andrade et al., 2005).

\section{Implications for glaucoma}

TRPV4 localization to the NFL, ONH and the proximal optic nerve together with proapoptotic effects of sustained TRPV4 channel stimulation appear to implicate this channel in the initiation and progression of glaucomatous remodeling. The pressure-induced activation range of TRPV4 $(10-30 \mathrm{mmHg})$ (Loukin et al., 2010b) matches the sustained IOP elevations in chronic glaucoma that can span a range of 10 to several tens of $\mathrm{mmHg}$ over the control value of $10-15 \mathrm{mmHg}$ (Bonomi et al., 2001; Quigley, 2005; Whitmore et al., 2005). Increases in hydrostatic or intraocular pressure are correlated with RGC death in cell cultures (Tezel and Wax, 2000; Agar et al., 2006), isolated retinas (Resta et al., 2007), the acute rat glaucoma model (Morrison et al., 1997), the chronic DBA/2J mouse model (John et al., 1998; Libby et al., 2005b), and human glaucoma patients (Bonomi et al., 2001; Gordon et al., 2002), whereas lowering of the IOP slows the progression of axonal loss at all stages of glaucomatous degeneration (Quigley, 2005). Rapid and severe IOP rises (such as occur in acute angle closure glaucoma) (Saw et al., 2003) may cause RGC loss within hours (Naskar et al., 2002) by compromising RGC function at their axons (Quigley, 1983) and their cell bodies (Libby et al., 2005a; Agar et al., 2006; Liu et al., 2007).

Our calcium imaging and immunolocalization experiments suggest that RGC perikarya and axons could be targeted by changes in mechanical and osmotic pressure. At the level of the perikaryon, $\left[\mathrm{Ca}^{2+}\right]_{\mathrm{RGC}}$ increases induced by membrane stretch and TRPV4 agonists had maximal amplitudes comparable to levels evoked by intense stimulation of ionotropic glutamate receptors. Consistent with the hypothesis that RGCs represent the first responder to an acute increase in IOP is the finding that the cornea-positive arm of the scotopic threshold response, the component of the visual ERG response that is the most sensitive to increased IOP, has a significant contribution from RGCs (Bui and Fortune, 2004; Kong et al., 2009). While retinal astrocytes and microglia were not immunolabeled by the TRPV4 antibody, it remains to be determined whether retinal glial TRPV4 expression is affected by sustained IOP increases, a possibility based on TRPV4 expression in cortical astrocytes (Benfenati et al., 2007) and the sensitivity of astrocyte $\mathrm{Ca}^{2+}$ homeostasis to increases in hydrostatic pressure (Mandal et al., 2010).

While the Trpv4 gene plays a critical function in regulation of systemic tonicity in mammals (Liedtke et al., 2000; Bourque, 2008; McHugh et al., 2010), inappropriate activation of TRPV4 in rodents and canines produces an acute circulatory collapse associated with edema, pulmonary hypertension, endothelial injury, ischemia, and/or cell death (Willette et al., 2008). We report that sustained exposure to TRPV4 agonists compromises the viability of mouse RGCs by triggering the apoptotic process, consistent with the observation that even low levels of elevated $\left[\mathrm{Ca}^{2+}\right]_{\mathbf{i}}$ are toxic for RGCs if sustained over an extended period of time (Hartwick et al., 2008). RGCs express the PAR-2 receptor that has been implicated in sensitization of TRPV4 to mechanical stimuli (Luo et al., 2005; Grant et al., 2007). Moreover, gain-offunction TRPV4 mutations cause a range of cellular problems that include axonal neuropathy and suppression of growth (Camacho et al., 2010; Loukin et al., 2010b; Zimoń et al., 2010). Thus, antagonizing excessive TRPV4 activation may be protective against apoptosis in RGCs stressed by sustained mechanical and/or osmotic stimulation.

Together, our data indicate the presence, in mammalian RGCs, of a novel background cation-permeable channel that confers mechanical/pressure sensitivity to cells that convey lightevoked signals to visual centers in the brain. The TRPV4 mechanism in RGCs represents a prime molecular target for severe blinding diseases such as diabetic retinopathy and glaucoma.

\section{References}

Agar A, Li S, Agarwal N, Coroneo MT, Hill MA (2006) Retinal ganglion cell line apoptosis induced by hydrostatic pressure. Brain Res 1086:191-200. Alessandri-Haber N, Dina OA, Chen X, Levine JD (2009) TRPC1 and TRPC6 channels cooperate with TRPV4 to mediate mechanical hyperalgesia and nociceptor sensitization. J Neurosci 29:6217-6228.

Andrade YN, Fernandes J, Vázquez E, Fernández-Fernández JM, Arniges M, Sánchez TM, Villalón M, Valverde MA (2005) TRPV4 channel is involved in the coupling of fluid viscosity changes to epithelial ciliary activity. J Cell Biol 168:869-874.

Becker D, Blase C, Bereiter-Hahn J, Jendrach M (2005) TRPV4 exhibits a functional role in cell-volume regulation. J Cell Sci 118:2435-2440.

Benfenati V, Amiry-Moghaddam M, Caprini M, Mylonakou MN, Rapisarda C, Ottersen OP, Ferroni S (2007) Expression and functional characterization of transient receptor potential vanilloid-related channel 4 (TRPV4) in rat cortical astrocytes. Neuroscience 148:876-892.

Bonomi L, Marchini G, Marraffa M, Morbio R (2001) The relationship be- 
tween intraocular pressure and glaucoma in a defined population: data from the Egna-Neumark glaucoma study. Ophthalmologica 215:34-38.

Bourque CW (2008) Central mechanisms of osmosenstation and systemic osmoregulation. Nat Rev Neurosci 9:519-531.

Brierley SM, Page AJ, Hughes PA, Adam B, Liebregts T, Cooper NJ, Holtmann G, Liedtke W, Blackshaw LA (2008) Selective role for TRPV4 ion channels in visceral sensory pathways. Gastroenterology 134:2059-2069.

Bui BV, Fortune B (2004) Ganglion cell contributions to the rat full-field electroretinogram. J Physiol 555:153-173.

Camacho N, Krakow D, Johnykutty S, Katzman PJ, Pepkowitz S, Vriens J, Nilius B, Boyce BF, Cohn DH (2010) Dominant TRPV4 mutations in nonlethal and lethal metatropic dysplasia. Am J Med Genet A 152A: $1169-1177$.

Christensen AP, Corey DP (2007) TRP channels in mechanosensation: direct of indirect activation? Nat Rev Neurosci 8:510-521.

Copeland NG, Jenkins NA, Court DL (2001) Recombineering: a powerful new tool for mouse functional genomics. Nat Rev Genet 2:769-779.

Dmitriev AV, Govardovskii VI, Schwahn HN, Steinberg RH (1999) Lightinduced changes of extracellular ions and volume in the isolated chick retina-pigment epithelium preparation. Vis Neurosci 16:1157-1167.

Duncan JL, Yang H, Doan T, Silverstein RS, Murphy GJ, Nune G, Liu X, Copenhagen D, Tempel BL, Rieke F, Križaj D (2006) Scotopic visual signaling in the mouse retina is modulated by high-affinity plasma membrane calcium extrusion. J Neurosci 26:7201-7211.

Gavrieli Y, Sherman Y, Ben-Sasson SA (1992) Identification of programmed cell death in situ via specific labeling of nuclear DNA fragmentation. J Cell Biol 119:493-501.

Gordon MO, Beiser JA, Brandt JD, Heuer DK, Higginbotham EJ, Johnson CA, Keltner JL, Miller JP, Parrish RK 2nd, Wilson MR, Kass MA (2002) The ocular hypertension treatment study. Arch Ophthalmol 120:714-720.

Grant AD, Cottrell GS, Amadesi S, Trevisani M, Nicoletti P, Materazzi S, Altier C, Cenac N, Zamponi GW, Bautista-Cruz F, Lopez CB, Joseph EK, Levine JD, Liedtke W, Vanner S, Vergnolle N, Geppetti P, Bunnett NW (2007) Protease-activated receptor 2 sensitizes the transient receptor potential vanilloid 4 ion channel to cause mechanical hyperalgesia in mice. J Physiol 578:715-733.

Grüsser OJ, Grüsser-Cornehls U, Kusel R, Przybyszewski AW (1989) Responses of retinal ganglion cells to eyeball deformation: a neurophysiological basis for "pressure phosphenes." Vision Res 29:181-194.

Güler AD, Lee H, Iida T, Shimizu I, Tominaga M, Caterina M (2002) Heatevoked activation of the ion channel, TRPV4. J Neurosci 22:6408-6414.

Gustin MC, Zhou XL, Martinac B, Kung C (1988) A mechanosensitive ion channel in the yeast plasma membrane. Science 242:762-765.

Hartmannsgruber V, Heyken WT, Kacik M, Kaistha A, Grgic I, Harteneck C, Liedtke W, Hoyer J, Köhler R (2007) Arterial response to shear stress critically depends on endothelial TRPV4 expression. PLoS ONE 2:e827.

Hartwick AT, Hamilton CM, Baldridge WH (2008) Glutamatergic calcium dynamics and deregulation of rat retinal ganglion cells. J Physiol 586:3425-3446.

Hayashida Y, Ishida AT (2004) Dopamine receptor activation can reduce voltage-gated $\mathrm{Na}^{+}$current by modulating both entry into and recovery from inactivation. J Neurophysiol 92:3134-3141.

Huang B, Karwoski CJ (1992) Light-evoked expansion of subretinal space volume in the retina of the frog. J Neurosci 12:4243-4252.

Jeon CJ, Strettoi E, Masland RH (1998) The major cell populations of the mouse retina. J Neurosci 18:8936-8946.

John SW, Smith RS, Savinova OV, Hawes NL, Chang B, Turnbull D, Davisson M, Roderick TH, Heckenlively JR (1998) Essential iris atrophy, pigment dispersion, and glaucoma in DBA/2j mice. Invest Ophthalmol Vis Sci 39:951-962.

Kim KJ, Rieke F (2003) Slow $\mathrm{Na}^{+}$inactivation and variance adaptation in salamander retinal ganglion cells. J Neurosci 23:1506-1516.

Kong YX, Crowston JG, Vingrys AJ, Trounce IA, Bui VB (2009) Functional changes in the retina during and after acute intraocular pressure elevation in mice. Invest Ophthalmol Vis Sci 50:5732-5740.

Križaj D (2005) Compartmentalization of calcium entry pathways in mouse rods. Eur J Neurosci 22:3292-3296.

Kung C (2005) A possible unifying principle for mechanosensation. Nature 436:647-654.

Leonelli M, Martins DO, Kihara AH, Britto LR (2009) Ontogenetic expres- sion of the vanilloid receptors TRPV1 and TRPV2 in the rat retina. Int J Dev Neurosci 27:709-718.

Libby RT, Li Y, Savinova OV, Barter J, Smith RS, Nickells RW, John SW (2005a) Susceptibility to neurodegeneration in a glaucoma is modified by Bax gene dosage. PLoS Genet 1:17-26.

Libby RT, Gould DB, Anderson MG, John SW (2005b) Complex genetics of glaucoma susceptibility. Annu Rev Genomics Hum Genet 6:15-44.

Liedtke W, Friedman JM (2003) Abnormal osmotic regulation in trpv4 $4^{-1-}$ mice. Proc Natl Acad Sci U S A 100:13698-13703.

Liedtke W, Kim C (2005) Functionality of the TRPV subfamily of TRP ion channels: add mechano-TRP and osmo-TRP to the lexicon! Cell Mol Life Sci 62:2985-3001.

Liedtke W, Choe Y, Martí-Renom MA, Bell AM, Denis CS, Sali A, Hudspeth AJ, Friedman JM, Heller S (2000) Vanilloid receptor-related osmotically activated channel (VR-OAC), a candidate vertebrate osmoreceptor. Cell 103:525-535.

Liedtke W, Tobin DM, Bargmann CI, Friedman JM (2003) Mammalian TRPV4 (VR-OAC) directs behavioral responses to osmotic and mechanical stimuli in Caenorhabditis elegans. Proc Natl Acad Sci U SA 100:14531-14536.

Liu Q, Ju WK, Crowston JG, Xie F, Perry G, Smith MA, Lindsey JD, Weinreb RN (2007) Oxidative stress is an early event in hydrostatic pressureinduced retinal ganglion cell damage. Invest Ophthalmol Vis Sci 48:4580-4589.

Liu W, Khare SL, Liang X, Peters MA, Liu X, Cepko CL, Xiang M (2000) All Brn3 genes can promote retinal ganglion cell differentiation in the chick. Development 127:3237-3247.

Loukin SH, Su Z, Kung C (2009) Hypotonic shocks activate rat TRPV4 in yeast in the absence of polyunsaturated fatty acids. FEBS Lett 583:754-758.

Loukin S, Su Z, Zhou X, Kung C (2010a) Forward genetic analysis reveals multiple gating mechanisms of TRPV4. J Biol Chem 285:19884-19890.

Loukin S, Zhou X, Su Z, Saimi Y, Kung C (2010b) Wild-type and brachyolmia-causing mutant TRPV4 channels respond directly to stretch force. J Biol Chem 285:27176-27181.

Luo W, Wang Y, Reiser G (2005) Two types of protease-activated receptors (PAR-1 and PAR-2) mediate calcium signaling in rat retinal ganglion cells RGC-5. Brain Res 1047:159-167.

Maingret F, Fosset M, Lesage F, Lazdunski M, Honoré E (1999) TRAAK is a mammalian neuronal mechano-gated $\mathrm{K}+$ channel. J Biol Chem 274:1381-1387.

Mandal A, Shahidullah M, Delamere NA (2010) Hydrostatic pressureinduced release of stored calcium in cultured rat optic nerve head astrocytes. Invest Ophthalmol Vis Sci 51:3129-3138.

Margolis DJ, Gartland AJ, Euler T, Detwiler PB (2010) Dendritic calcium signaling in $\mathrm{ON}$ and OFF mouse retinal ganglion cells. J Neurosci 30:7127-7138.

May CA, Nakamura K, Fujiyama F, Komatsu Y, Yanagawa Y (2007) Homozygous GAD65 and heterozygous GAD67 knock-out mice reveal normal retinal development and maintenance despite reduced amounts of GABA. Acta Neuropathol 113:101-103.

McHugh J, Keller NR, Appalsamy M, Thomas SA, Raj SR, Diedrich A, Biaggioni I, Jordan J, Robertson D (2010) Portal osmopressor mechanism linked to transient receptor potential vanilloid 4 and blood pressure control. Hypertension 55:1438-1443.

Mendoza SA, Fang J, Gutterman DD, Wilcox DA, Bubolz AH, Li R, Suzuki M, Zhang DX (2010) TRPV4-mediated endothelial $\mathrm{Ca}^{2+}$ influx and vasodilation in response to shear stress. Am J Physiol Heart Circ Physiol 298:H466-H476.

Morrison JC, Moore CG, Deppmeier LM, Gold BG, Meshul CK, Johnson EC (1997) A rat model of chronic pressure-induced optic nerve damage. Exp Eye Res 64:85-96.

Nadal-Nicolás FM, Jiménez-López M, Sobrado-Calvo P, Nieto-López L, Cánovas-Martínez I, Salinas-Navarro M, Vidal-Sanz M, Agudo M (2009) Brn3a as a marker of retinal ganglion cells: qualitative and quantitative time course studies in naïve and optic nerve-injured retinas. Invest Ophthalmol Vis Sci 50:3860-3868.

Naruse K, Yamada T, Sokabe M (1998) Involvement of SA channels in orienting response of cultured endothelial cells to cyclic stretch. Am J Physiol 274:H1532-H1538.

Naskar R, Wissing M, Thanos S (2002) Detection of early neuron degener- 
ation and accompanying microglial responses in the retina of a rat model of glaucoma. Invest Ophthalmol Vis Sci 43:2962-2968.

Neher E (1995) The use of fura-2 for estimating Ca buffers and Ca fluxes. Neuropharmacology 34:1423-1442.

Newman EA (2001) Calcium signaling in retinal glial cells and its effect on neuronal activity. Prog Brain Res 132:241-254.

O'Neil RG, Heller S (2005) The mechanosensitive nature of TRPV channels. Pflugers Arch 451:193-203.

Otori Y, Wei JY, Barnstable CJ (1998) Neurotoxic effects of low doses of glutamate on purified rat retinal ganglion cells. Invest Ophthalmol Vis Sci 39:972-981.

Ozaita A, Petit-Jacques J, Völgyi B, Ho CS, Joho RH, Bloomfield SA, Rudy B (2004) A unique role for Kv3 voltage-gated potassium channels in starburst amacrine cell. J Neurosci 24:7335-7343.

Perry VH, Walker M (1980) Amacrine cells, displaced amacrine cells and interplexiform cells in the retina of the rat. Proc R Soc Lond B Biol Sci 208:415-431.

Phan MN, Leddy HA, Votta BJ, Kumar S, Levy DS, Lipshutz DB, Lee SH, Liedtke W, Guilak F (2009) Functional characterization of TRPV4 as an osmotically sensitive ion channel in porcine articular chondrocytes. Arthritis Rheum 60:3028-3037.

Quigley HA (1983) Experimental glaucoma damage mechanism. Arch Ophthalmol 101:1301-1302.

Quigley HA (2005) Glaucoma: macrocosm to microcosm the Friedenwald Lecture. Invest Ophthalmol Vis Sci 26:2662-2670.

Raoux M, Rodat-Despoix L, Azorin N, Giamarchi A, Hao J, Maingret F, Crest M, Coste B, Delmas P (2007) Mechanosensor channels in mammalian somatosensory neurons. Sensors 7:1667-1682.

Raymond ID, Pool AL, Vila A, Brecha NC (2009) A thyl-CFP DBA/2J mouse line with cyan fluorescent protein expression in retinal ganglion cells. Vis Neurosci 26:453-465.

Reiter B, Kraft R, Günzel D, Zeissig S, Schulzke JD, Fromm M, Harteneck C (2006) TRPV4-mediated regulation of epithelial permeability. FASEB J 20:1802-1812.

Rentería RC, Tian N, Cang J, Nakanishi S, Stryker MP, Copenhagen DR (2006) Intrinsic ON responses of the retinal OFF pathway are suppressed by the ON pathway. J Neurosci 26:11857-11869.

Resta V, Novelli E, Vozzi G, Scarpa C, Caleo M, Ahluwalia A, Solini A, Santini E, Parisi V, Di Virgilio F, Galli-Resta L (2007) Acute retinal ganglion cell injury caused by intraocular pressure spikes is mediated by endogenous extracellular ATP. Eur J Neurosci 25:2741-2754.

Reyes R, Lauritzen I, Lesage F, Ettaiche M, Fosset M, Lazdunski M (2000) Immunolocalization of the arachidonic acid and mechanosensitive baseline traak potassium channel in the nervous system. Neuroscience 95:893-901.

Sappington RM, Sidorova T, Long DJ, Calkins DJ (2009) TRPV1: contribution to retinal ganglion cell apoptosis and increased intracellular $\mathrm{Ca}^{2+}$ with exposure to hydrostatic pressure. Invest Ophthalmol Vis Sci 50:717-728.

Saw SM, Gazzard G, Friedman DS (2003) Interventions for angle-closure glaucoma: an evidence-based update. Ophthalmology 110:1869-1878.

Sharif-Naeini R, Ciura S, Zhang Z, Bourque CW (2008) Contribution of TRPV channels to osmosensory transduction, thirst, and vasopressin release. Kidney Int 73:811-815.

Shibasaki K, Suzuki M, Mizuno A, Tominaga M (2007) Effects of body temperature on neural activity in the hippocampus: regulation of resting membrane potentials by transient receptor potential vanilloid 4 . J Neurosci 27:1566-1575.

Strotmann R, Harteneck C, Nunnenmacher K, Schultz G, Plant TD (2000) OTRPC4, a nonselective cation channel that confers sensitivity to extracellular osmolarity. Nat Cell Biol 2:695-702.

Suzuki M, Mizuno A, Kodaira K, Imai M (2003) Impaired pressure sensation with mice lacking TRPV4. J Biol Chem 278:22664-22668.
Szikra T, Barabas P, Bartoletti TM, Huang W, Akopian A, Thoreson WB, Križaj D (2009) Calcium homeostasis and cone signaling are regulated by interactions between calcium stores and plasma membrane ion channels. PLoS One 4:e6723.

Tezel G, Wax MB (2000) Increased production of tumor necrosis factoralpha by glial cells exposed to simulated ischemia or elevated hydrostatic pressure induces apoptosis in cocultured retinal ganglion cells. J Neurosci 20:8693-8700.

Thodeti CK, Matthews B, Ravi A, Mammoto A, Ghosh K, Bracha AL, Ingber DE (2009) TRPV4 channels mediate cyclic strain-induced endothelial cell reorientation through integrin-to-integrin signaling. Circ Res 104:1123-1130.

Thorneloe KS, Sulpizio AC, Lin Z, Figueroa DJ, Clouse AK, McCafferty GP, Chendrimada TP, Lashinger ES, Gordon E, Evans L, Misajet BA, Demarini DJ, Nation JH, Casillas LN, Marquis RW, Votta BJ, Sheardonw SA, Xu X, Brooks DP, Laping JN, et al. (2008) $N-((1 S)-1-\{[4-((2 S)-2-\{[(2,4-$ Dichlorophenyl)sulfonyl] amino \}-3-hydroxypropanoyl)-1-piperazinyl] carbonyl\}-3-methylbutyl)-1-benzothiophene-2-carboxamide (GSK1016790A), a novel and potent transient receptor potential vanilloid 4 channel agonist induces urinary bladder contraction and hyperactivity: Part I. J Pharmacol Exp Ther 326:432-442.

Vriens J, Watanabe H, Janssens A, Droogmans G, Voets T, Nilius B (2004) Cell swelling, heat, and chemical agonists use distinct pathways for the activation of the cation channel TRPV4. Proc Natl Acad Sci U S A 101:396-401.

Vriens J, Owsianik G, Janssens A, Voets T, Nilius B (2007) Determinants of 4 alpha-phorbol sensitivity in transmembrane domains 3 and 4 of the cation channel TRPV4. J Biol Chem 282:12796-12803.

Wang JH, Thampatty BP (2006) An introductory review of cell mechanobiology. Biomech Model Mechanobiol 5:1-16.

Watanabe H, Davis JB, Smart D, Jerman JC, Smith GD, Hayes P, Vriens J, Cairns W, Wissenbach U, Prenen J, Flockerzi V, Droogmans G, Benham CD, Nilius B (2002) Activation of TRPV4 channels (hVRL-2/mTRP12) by phorbol derivatives. J Biol Chem 277:13569-13577.

Whitmore AV, Libby RT, John SW (2005) Glaucoma: thinking in new ways-a role for autonomous axonal self-destruction and other compartmentalised processes? Prog Retin Eye Res 24:639-662.

Willette RN, Bao W, Nerurkar S, Yue TL, Doe CP, Stankus G, Turner GH, Ju H, Thomas H, Fishman CE, Sulpizio A, Behm DJ, Hoffman S, Lin Z, Lozinskaya I, Casillas LN, Lin M, Trout RE, Votta BJ, Thorneloe K, et al. (2008) Systemic activation of the transient receptor potential V4 channel causes endothelial failure and circulatory collapse. J Pharmacol Exp Ther 326:443-452.

Wu X, Davis MJ (2001) Characterization of stretch-activated cation current in coronary smooth muscle cells. Am J Physiol Heart Circ Physiol 280:H1751-H1761.

Zabel M, Koller BS, Sachs F, Franz MR (1996) Stretch-induced voltage changes in the isolated beating heart: importance of the timing of stretch and implications for stretch-activated ion channels. Cardiovasc Res 32:120-130.

Zhao S, Cunha C, Zhang F, Liu Q, Gloss B, Deisseroth K, Augustine GJ, Feng G (2008) Improved expression of halorhodopsin for light-induced silencing of neuronal activity. Brain Cell Biol 36:141-154.

Zhou ZJ, Fain GL (1996) Starburst amacrine cells change from spiking to nonspiking neurons during retinal development. Proc Natl Acad Sci U S A 93:8057-8062.

Zimoń M, Baets J, Auer-Grumbach M, Berciano J, Garcia A, Lopez-Laso E, Merlini L, Hilton-Jones D, McEntagart M, Crosby AH, Barisic N, Boltshauser E, Shaw CE, Landouré G, Ludlow CL, Gaudet R, Houlden H, Reilly MM, Fischbeck KH, Sumner CJ, Timmerman V, Jordanova A, Jonghe PD (2010) Dominant mutations in the cation channel gene transient receptor potential vanilloid 4 cause an unusual spectrum of neuropathies. Brain 133:1798-1809. 